فاعلية برنامج تدريبي مقترح في تنمية الخيال العلمي والجوانب المعرفية المرتبطة





\title{
مقدمة:
}

أحلام وخيال الإنسان معينّ لا ينضب أبدًا، وهو متجدد ومبد ومبدع دائمًا، فطالما










الأجداد، أو يتطلع للمستقبل ليرى الأحفاد.






بدايته خيال عالم أو أديب.


































فرواية جول فيرن (من الأرض إلى القمر)، ورواية جورج ويلز (أول إنسان

















ويتسم أدب الخيال العلمي بربط العالم بالتغيير ، وهو يذهب إلى إلى أبعد من التأمل






العلوم فى تطبيقاتها بآخيال العلمي.
















.2006, 30)

ويعتبر (Stutler, 2011, 45) الخيال العلمي وسيلة للطلاب لاكتساب المعرفة و المهار ات البحثية، و أساسًا لمسار ات التعلم المستقبلية بالنسبة لهم.








العلمي، تزيد من دافعية الطلاب لاستكثاف مفاهيم التعلوم بطريقة أكثر عمقا.








وتؤكد دراسة (2007)Bixler, أن استخدام الخيال العلمي في تدريس التطور

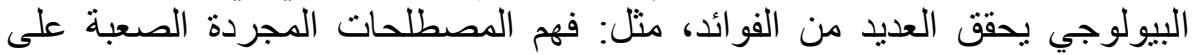


لمعرفتهم، وكسب الطلاب قليلي الاهتمام بالتطور البيولوجي لأسباب دينية أو لغير ها. و وندما استخدمت دراسة (Barnett, Kafka, 2007) فيلمين من أفلام

الخيال العلمي هما: The core \& Red plant في تدريس مقرر The living earth 2

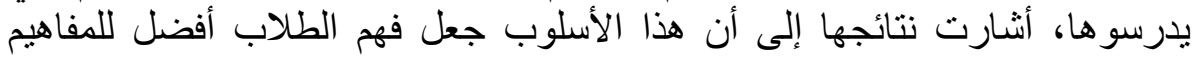
العلمية بالمقرر، ومندمجين في المحاضر ات الني التي تعتبر شيقة بالنسبة لهم.

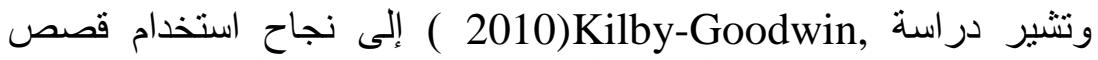
الخيال العلمي كنشاط إثرائي داخل فصول العلوم في زيادة ميول الطيات الطلاب للقراءة والبحث، وقدرتهم على كتابة الأفكار العلمية.

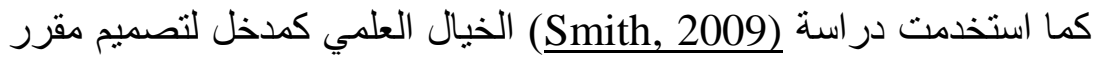


الطلاب للمفاهيم الفيزيائية، وتذكر ها بطريقة أفضل.







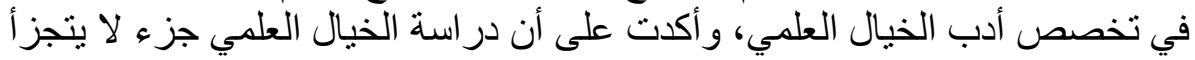

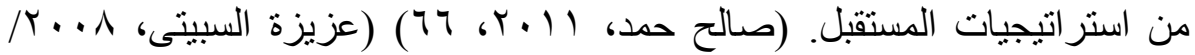

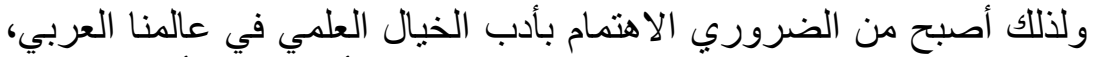

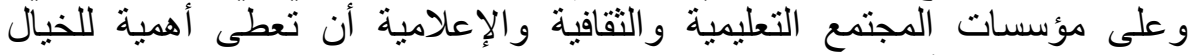

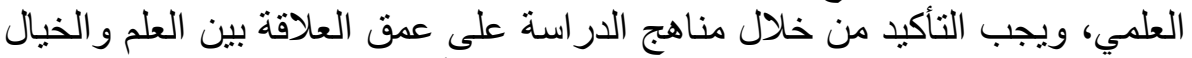

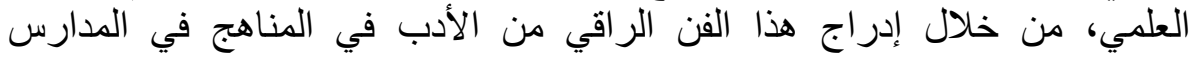


$(17 \cdot 6 r \cdot 14$

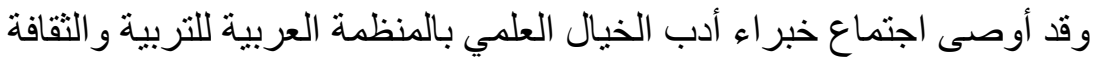



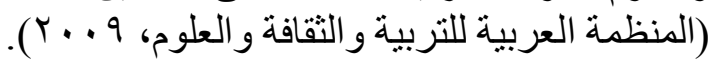




الإسنراتيجية، إلا أنه لا يزال ثقافة غريبة ألتا عن مجتمعاتنا العربية ونظمها التعليمية 
و الثقافية، مما يتطلب أهمية إعادة النظر فيها؛ لتنطرق لهذه الموضوعات المعاصرة

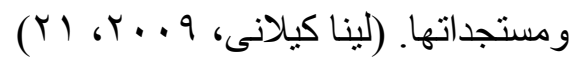

فأخطر ما تعانى منه نظم التعليم فى عالمنا العربى يكمن فى عدم إعطاء

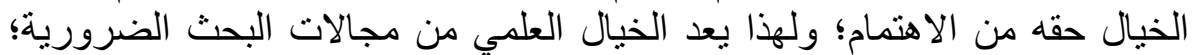





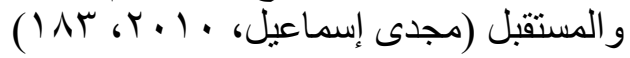

\section{الإحساس بالمشكثة:}

ومن خلال استعر اض الباحث للار اسات السابقة في موضوع الخيال العلمي

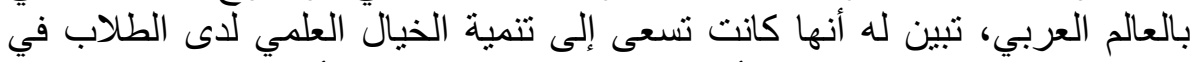

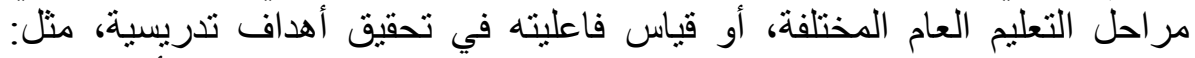

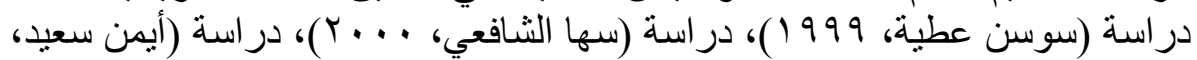

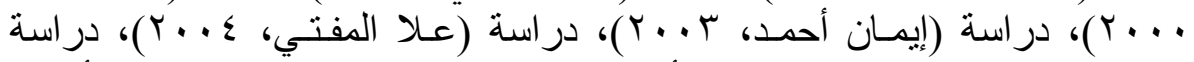

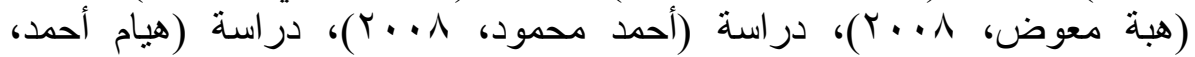

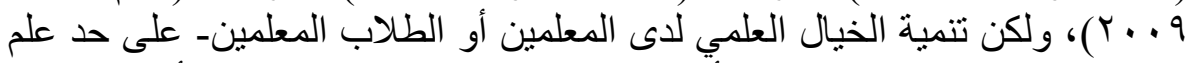



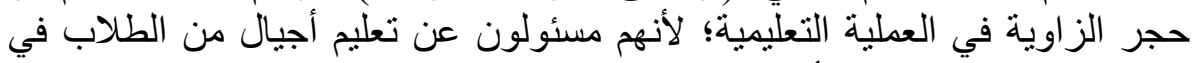

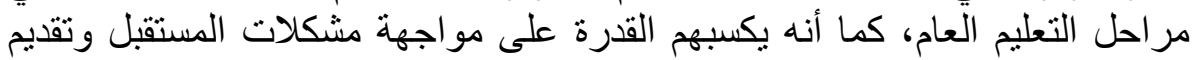

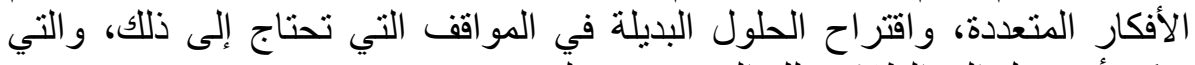
يمكن أن تنتقل إلي الطلاب تلك القدة، القدرة من معلميهم.



التوصية بتدريب معلمات الروضة على استخدام مداخل وطرق تدريس متنو عة لتنمية التفكير الحر و إثارة الخيال العلمي لدى الأطفال.



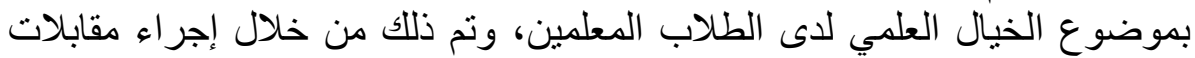
شخصية مفتوحة و غير مقننة مع ب ا طالب من طلاب الدبلوم العام فى التربية بعمادة


الأسئلة التي دارت حولة لها تلك الته المقابلات:

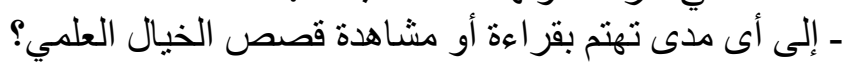

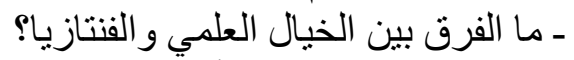
ـ هل يمكن الاستفادة من أدب الخيال العلمي في تدريس العلى العلوم؟ وكيف؟ وبتحليل استجابات الطلاب اتضح أن: ب طلاب فقط هم الذين شاهدوا أفلام خيال علمى، و لا يوجد طالب و احد قرأ قصة و احدة للخيال العلمي. 


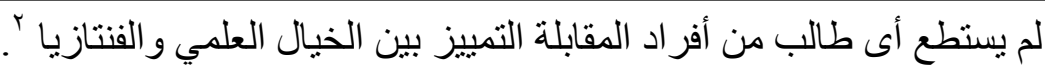

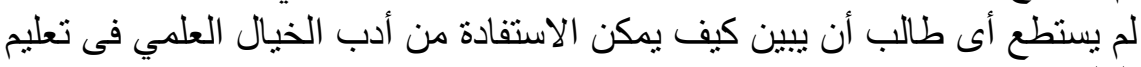

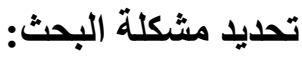

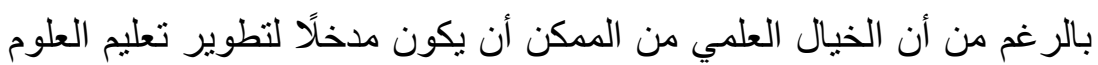

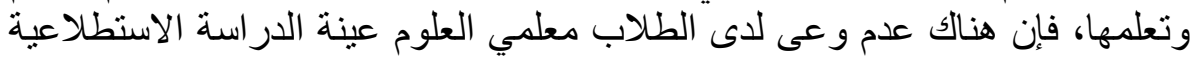

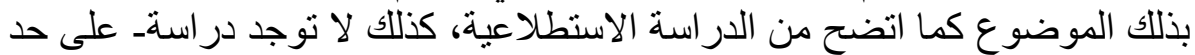



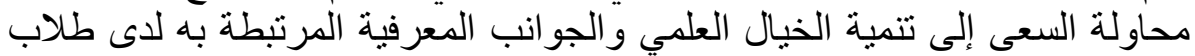





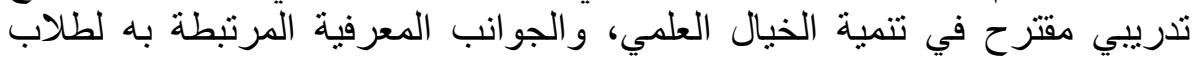


وقد تطلب ذلك الإجابة عن الأسئلة الآتية:

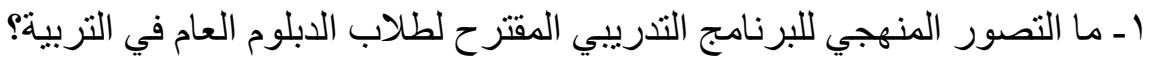



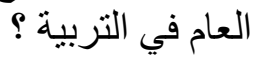
rـ ما فاعلية البرنامج التدريبي المقتر حس في تنمية الجو انب المعرفية المرتبطة بالخيال العلمى لطلاب الدبلوم العام في التربية ؟

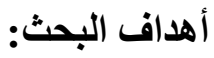

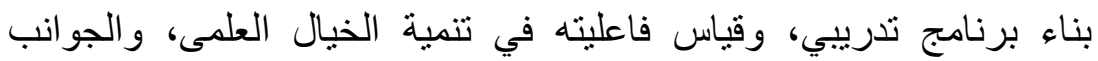


و التعليم المستمر بجامعة جاز انه لان.

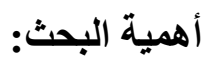

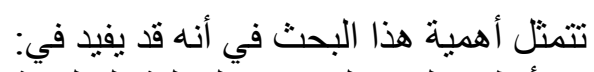



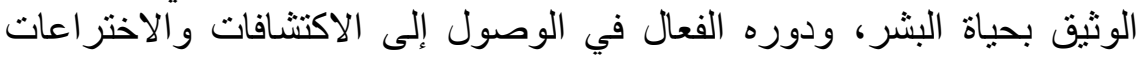

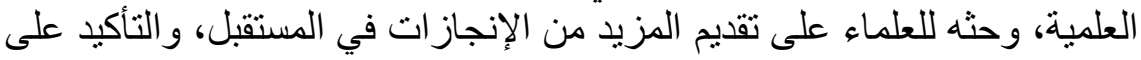

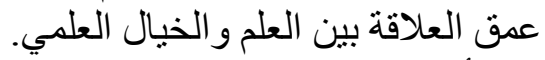
r. لفت أنظار المسئولين عن العملية التعليمية إلى دور أدب العيل الخيال العلمي في تنمية قدرة الطلاب على الخيال العلمي. 
r. تزويد معلمي العلوم والمشرفين التربويين بدليل يمكن الاسترشاد به في تتمية



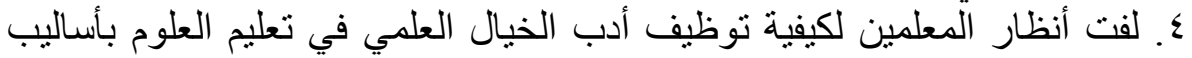
منهجية، تسهم في زيادة فاعلية عملية تعليم وتعلم العلوم.

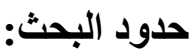

$$
\text { اقتصر البحث الحالي علي: ولتئ }
$$

ا ـ طلاب الدبلوم العام في التربية بعمادة خدمة المجتمع والتعليم المستمر بجامعة

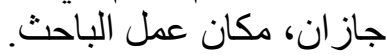
r ـ قياس الجوانب المعرفية المرتبطة بالخيال العلمى في مستويات (التذكر - الفهم-

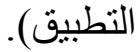
مصطحات البحث: - ان

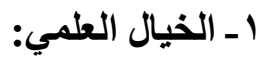

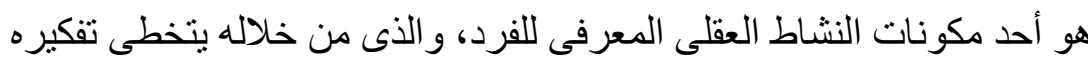



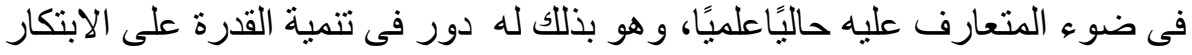

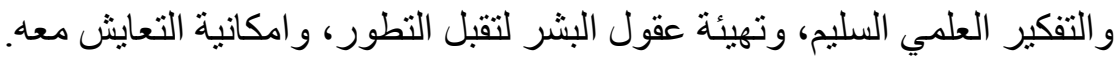

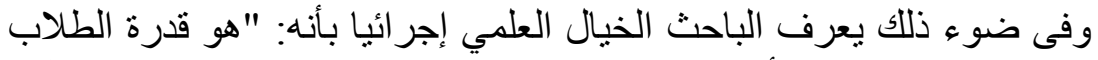

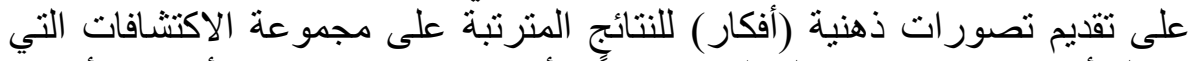

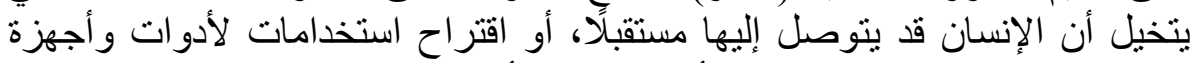

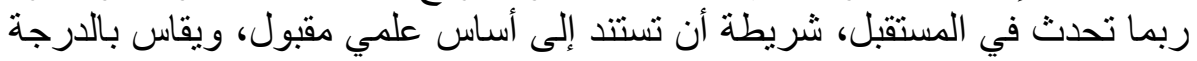


r ـ الجوانب المعرفية المرتبطة بالخيال العلمى:



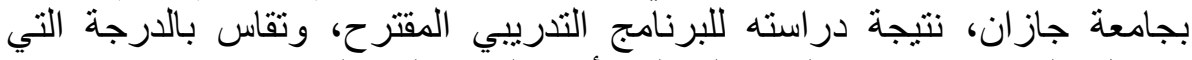

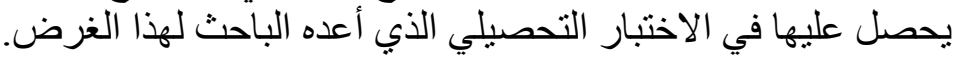

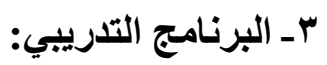

هو: خطة منظمة لتدريب مجموعة من الأفراد على إتقان مهارة معينة، و تتضمن الخطة أيضًا التوجيهات الخاصة بتنظيم إدارة البرنامج (مجمع اللغة العربية، (ᄉr 6) $9 \wedge \varepsilon$

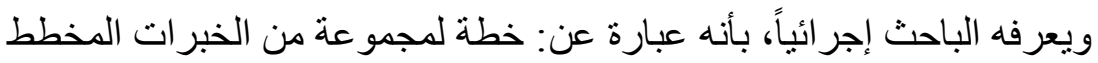

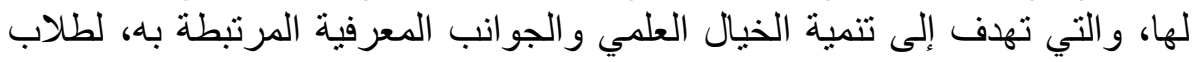
الدبلوم العام في التربية. 


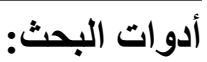

ا ـ أداة المعالجة التجريبية: وتتمثل في البرنامج التدريبي المقتر ح. (إعداد الباحث)

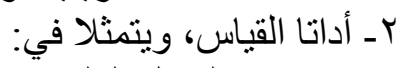
ـ اختبار الخيال العلمي. (إعداد الباحث) ـ اختبار تحصيلي في موضو عات البراد البرنامج المقتر ح. (إعداد الباحث)

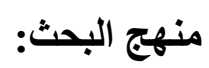

اتبع البحث الحالي المنهج التجريبي؛ لأنه يسعى لقياس فاعلية البرنامج

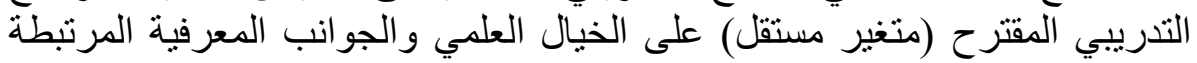
بالخيال العلمى للطلاب (متغير ان تابعان). فروض البحث:

1- لا يوجد فرق دال إحصائيًا عند مستوى (1 إ.. ) بين درجات المجموعتين

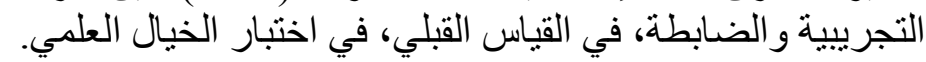

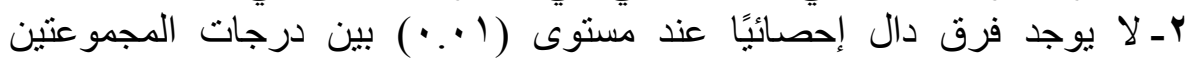

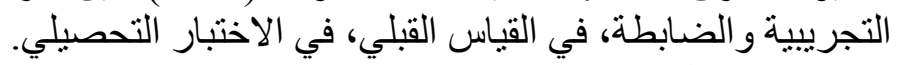

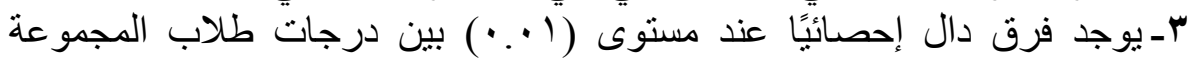
التجريبية في القياسين القبلي والبعدي، في اختبار الخيال العلمي لصالح التطبيق

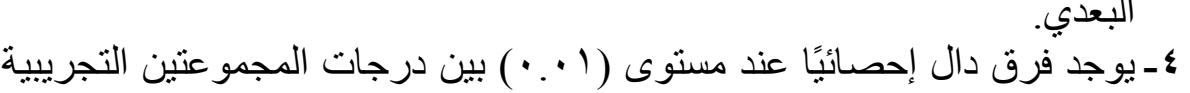

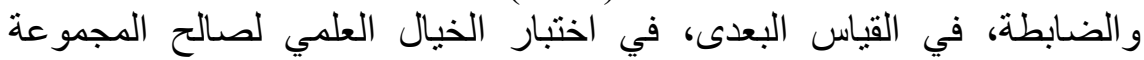
التجريبية .

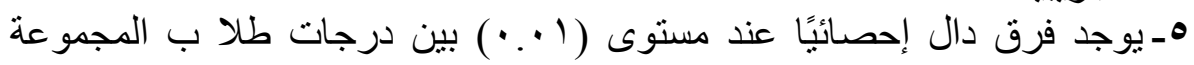

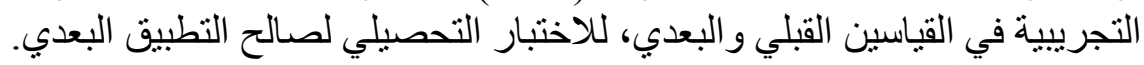

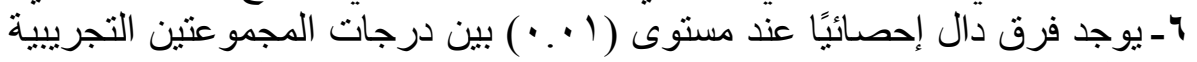

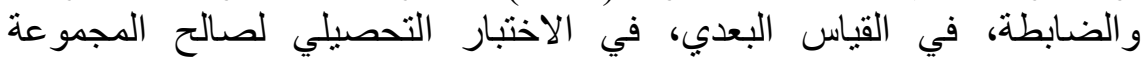
التجرييية . خطوات البحث: للإجابة عن تساؤلات البحث، والتأكد من صحة فروضه، سارت خطوات البحث وفق الخطو ات التالية:

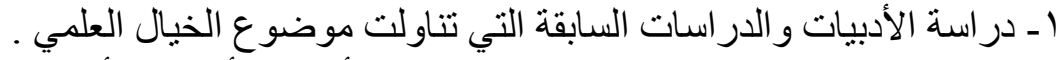

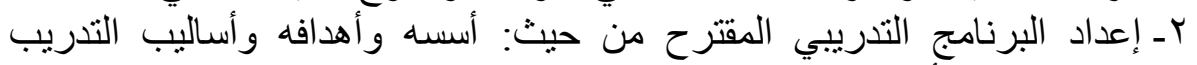
و التقويم، ثم التأكد من صـاحلاحيته.

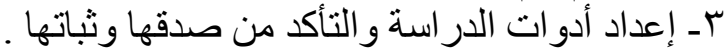

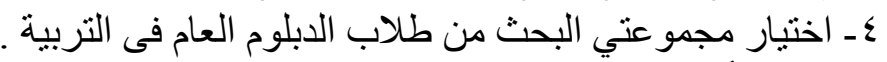

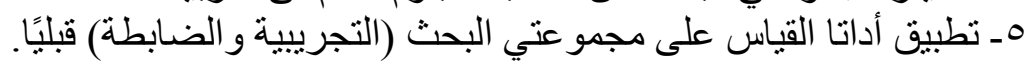

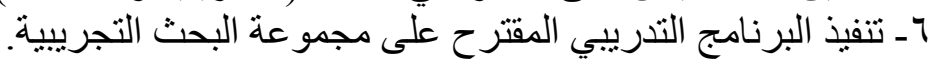


Vـ نطبيق أداتا القياس على مجمو عتي البحث (التجريبية و الضابطة) بعديًا.

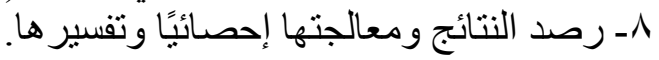

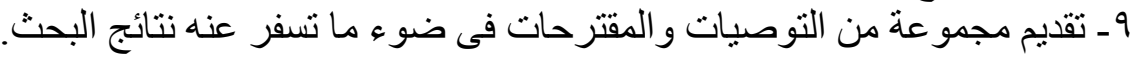

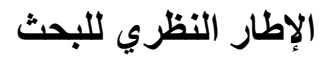

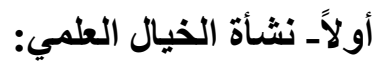

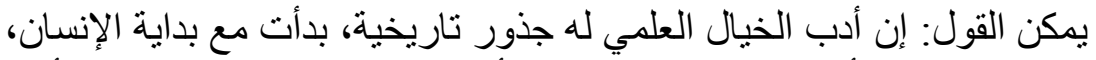

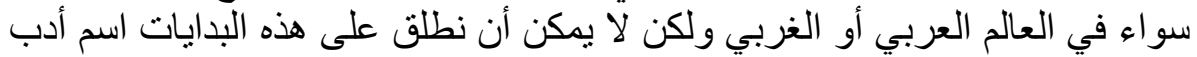

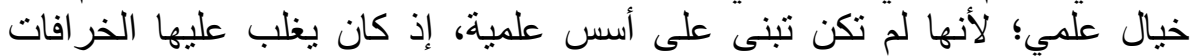
و الأساطير، ويمكن التميز بين الخيال العلمي في العالم الغربي و العالم العربي من لنئ

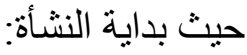

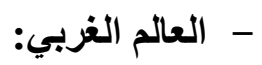

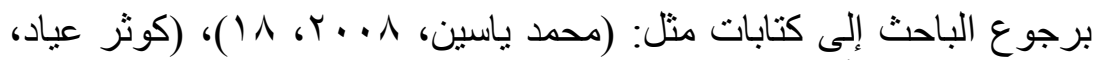

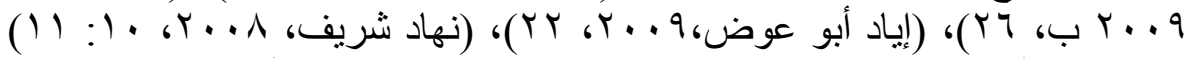

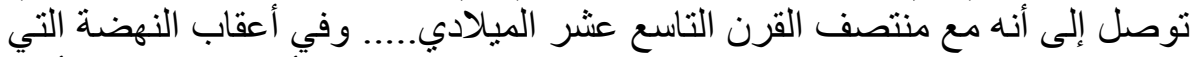

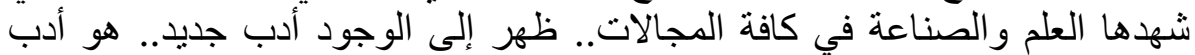

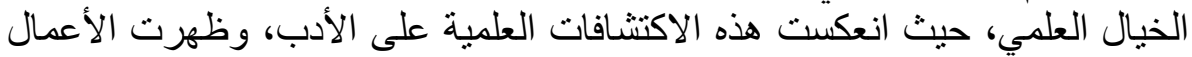

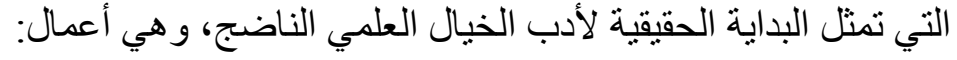

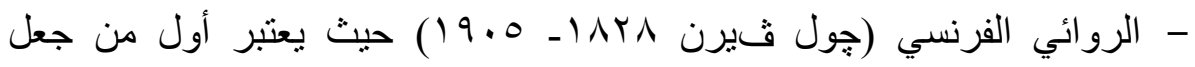

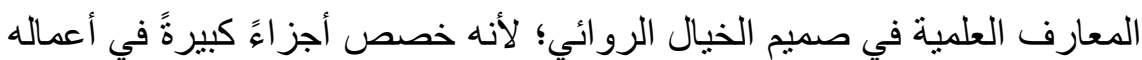
لوصف بعض التقنيات أو لتفسير بعض النظئ النظريات والظوانه الهر العلمية الفيزيائية منها أو الرياضية.

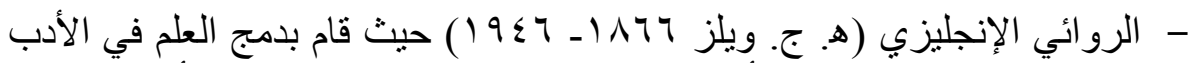

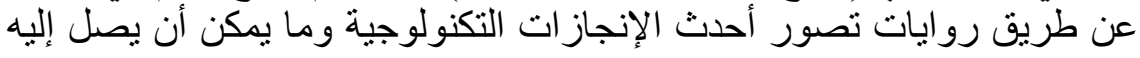

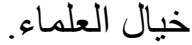

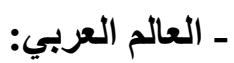

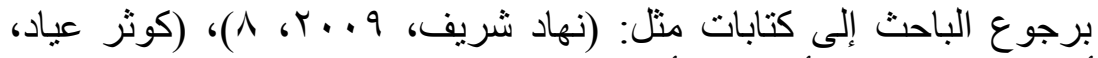

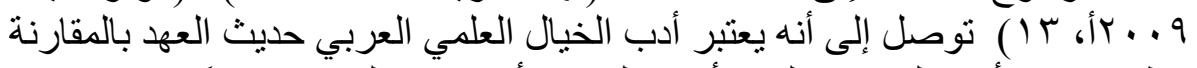

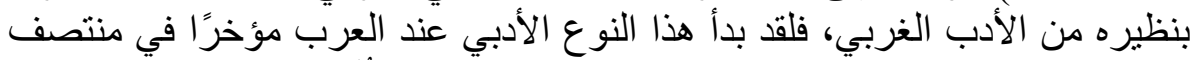
القرن العشرين، وقد بدأت مسيرة هذا اللون الأدبي بأعمال كُتّاب مثل: الأبر

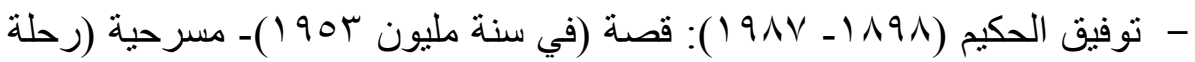

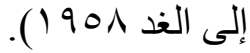

- وتلاه كتاب آخرون مثل يوسف عز الدين، ومصطفى محمود، ونهاد شريف،

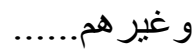




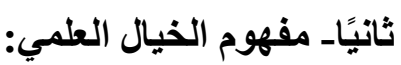

تعددت تعريفات الخيال العلمي منها:

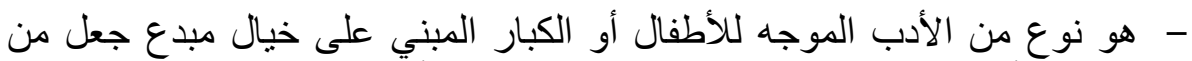

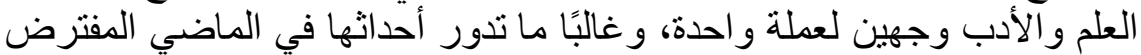

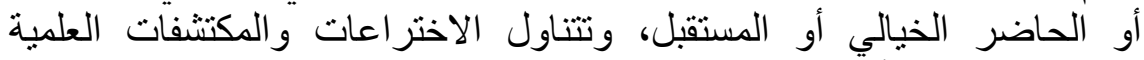
و التكنولوجية، و الأرض برًا وبحرًا وجوًا، و والفضاء والكاء والكائنات الغريبة، و الزمن.

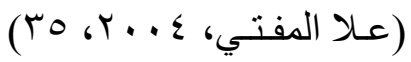

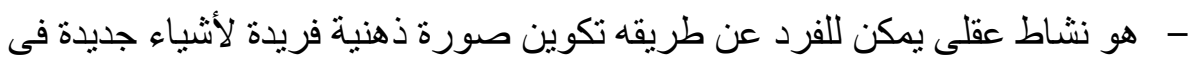

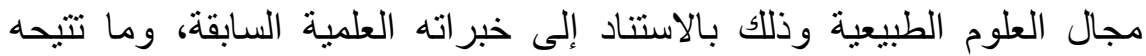

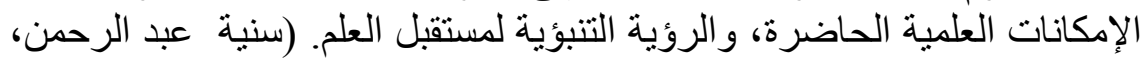

(ror G r... V

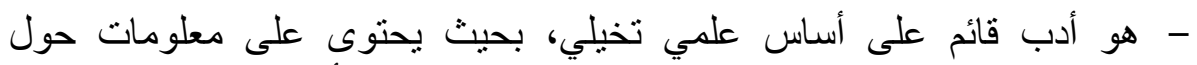

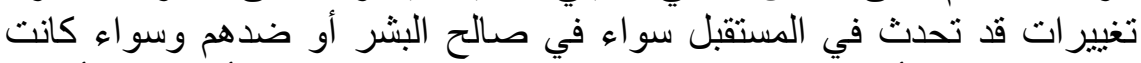

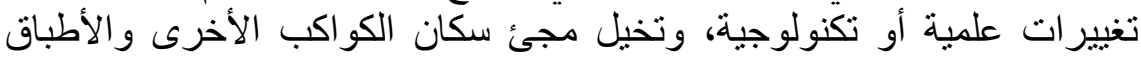

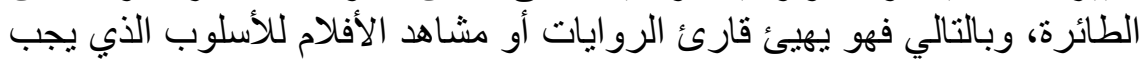

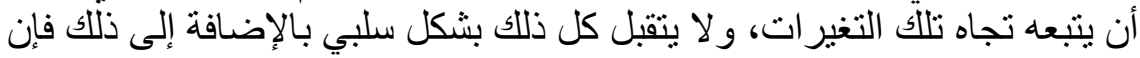

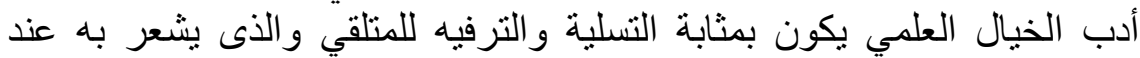

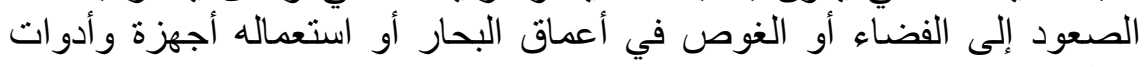

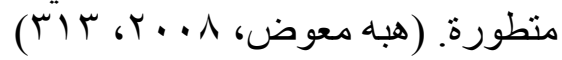

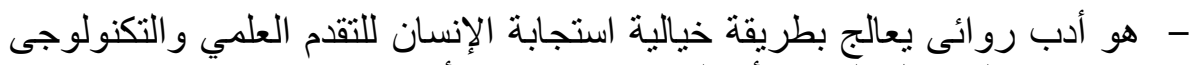

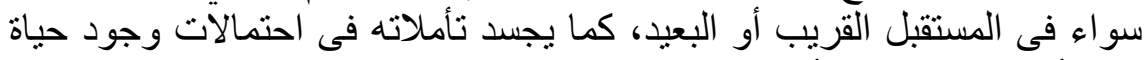

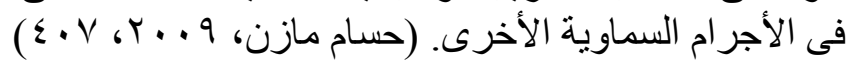

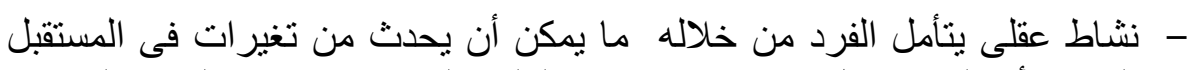

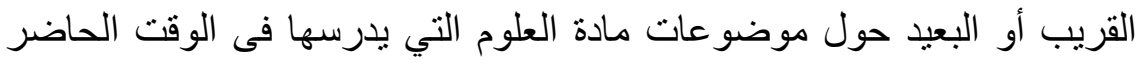

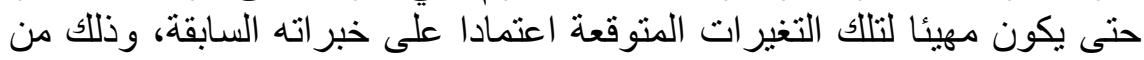

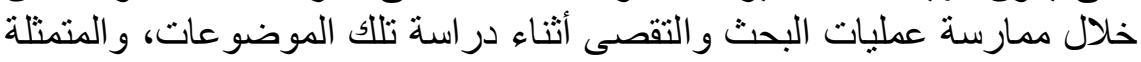

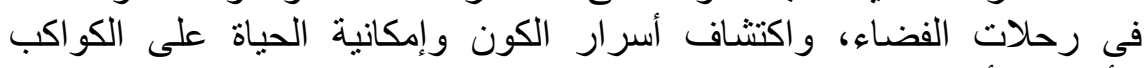

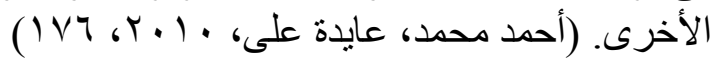

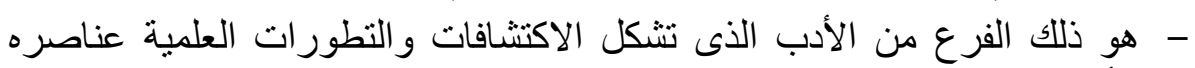
الأساسية، ويعتمد على التنبؤات المستقبلية واحتمالات العلم و التي قد تصبح و اقعية التهية

(Cavanaugh , Cavanaugh, 2004, 2)

- هو ذلك النوع من الأدب الذى يعالج موضوعات علمية بطريقة تخيلية منظمة

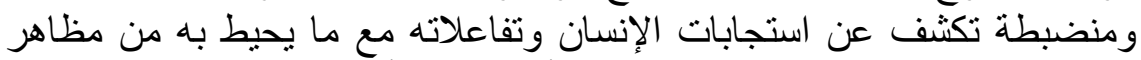

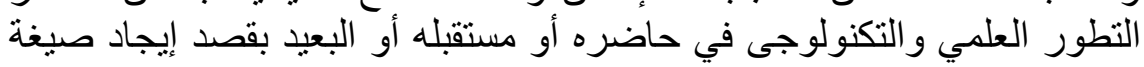

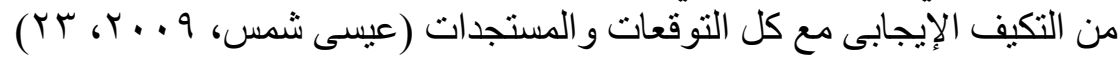


- بعد استعر اض التعريفات السابقة للخيال العلمي يمكن للباحث أن يستخلص بعض فئ

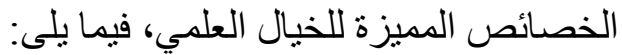
- يعد أحد مكونات النشاط العقلى المعرفى للفرد. - من خلاله يتخطى تفكير الفرد حاجز الزمان والمكان، و إتاحة الفرصة بين

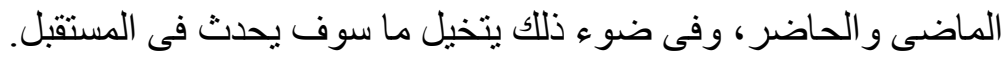
- - يعنى بالممكنات المبتكرة التي يمكن أن تحدث مستقبلا.

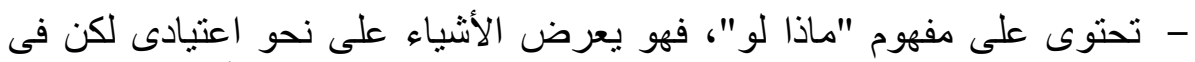

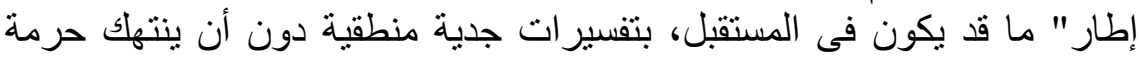
المتعارف عليه فى العلوم الحالية. - له دور كبير فى تتمية القدرة على الابتكار ، والتفكير العلمي السليم.

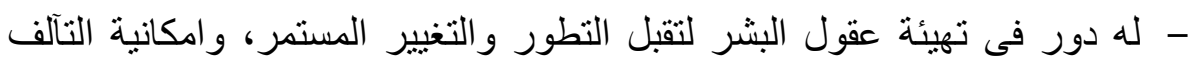

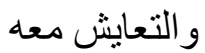

- ومن خلال تللك الخصائص، يرى الباحث أنه يمكن تعريف الخيال العلمي بأنه: هو أحد مكونات النشاط العقلى المعرفى للفرد، و الذى من خلاله يتخطى تفكيره

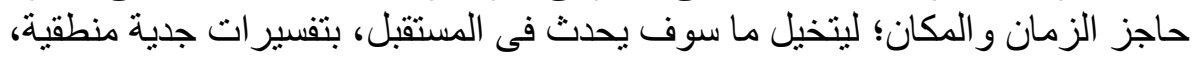

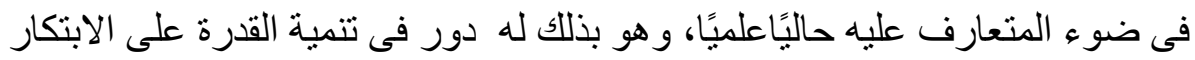

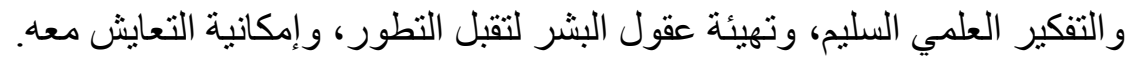
ثالثًا قضايا ومجالات الخيال العلمي:

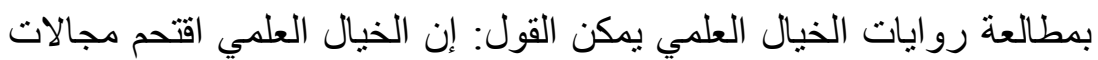

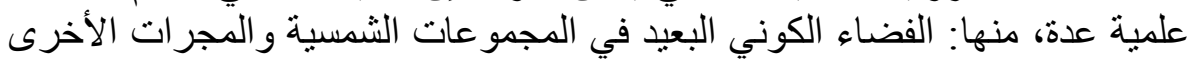

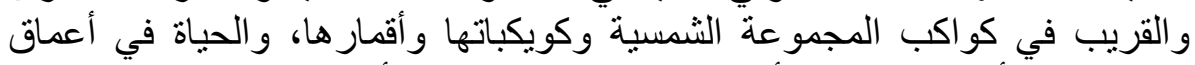

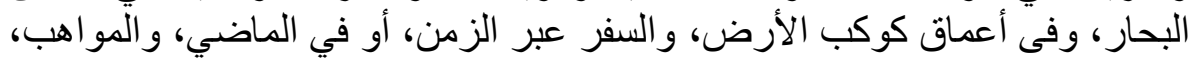

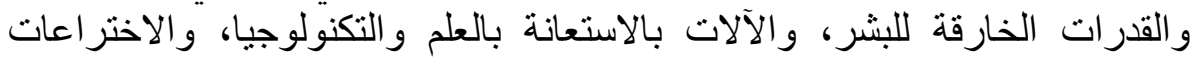

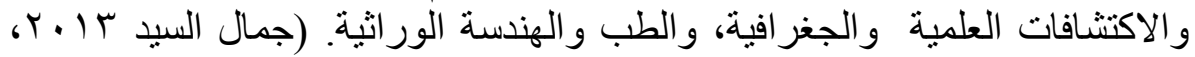

رابعًا: الدور التربوي للخيال العلمي في تدريس العلوم: يمكن للخيال العلمي أن يحقق مجموعة من الوظائف التربوية يمكن إجمالها

فيما يأتي: - تنمية الثقافة العلمية لدى الأطفال، من خلال تقديم الموضو عات بأسلوب قصصي، شيق وجذاب، وممتع.

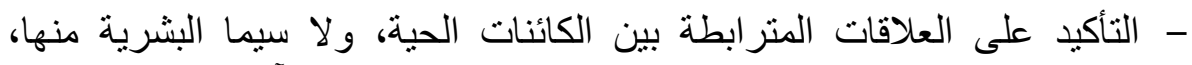

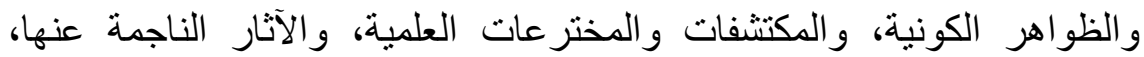
ودور الإنسان الإيجابي في ذلك. 


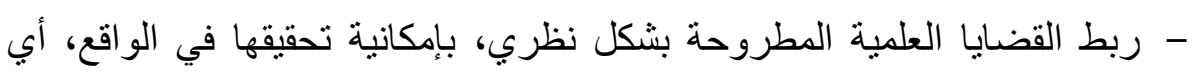

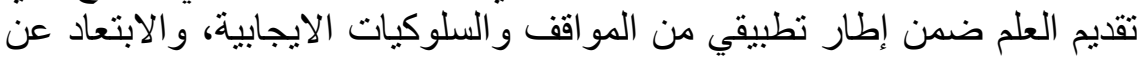

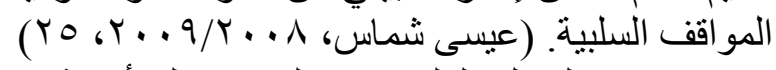

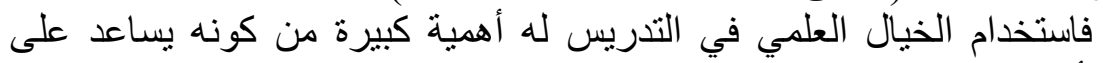

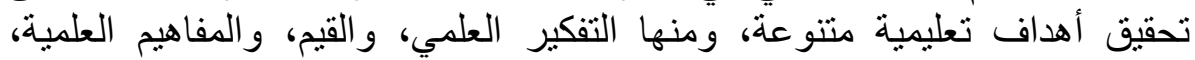
والاتجاهات العلمية، والقدرات الإبداعية، و الذهنية ويوسع آفاق المتعلمين العقلية ويحسن الجو التدريسي العام كون الخيال العلمي محبب للمتعلمين. (جمال السيد،

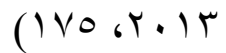

كما أن للخيال أهمية بالغة في إدراك المفاهيم العلمية؛ لأن المفهوم العلمي هو

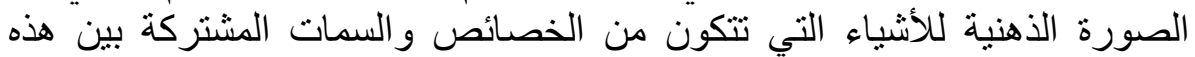

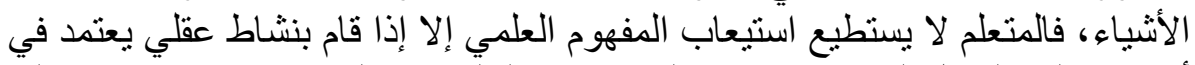

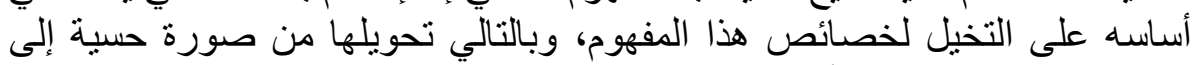

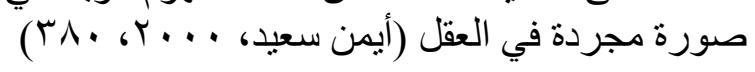

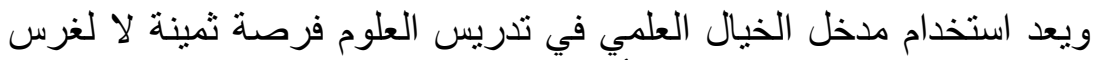

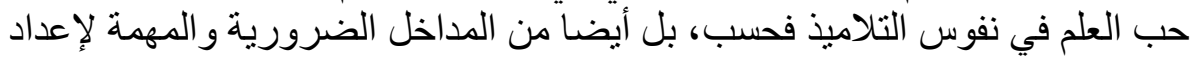

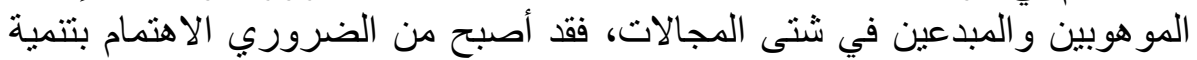

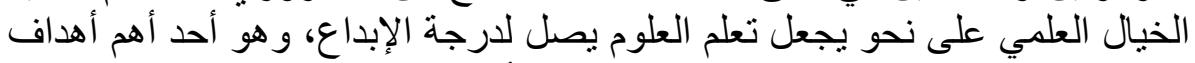
التربية العلمية الحديثة وخاصة في المراحل الأولى من التعليم. (مجدي إسماعيل، $(1 \wedge 76 \% \cdot 1$.

كما أن استخدام أفلام الخيال العلمي فى تدريس موضو عات العلوم ضرورى العى العي

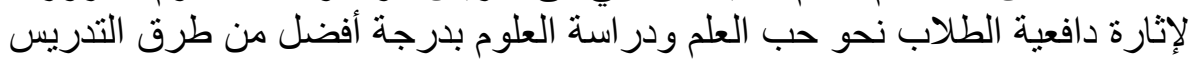

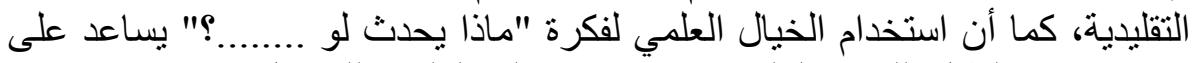

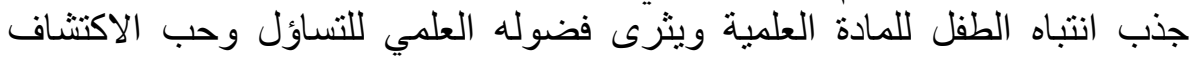

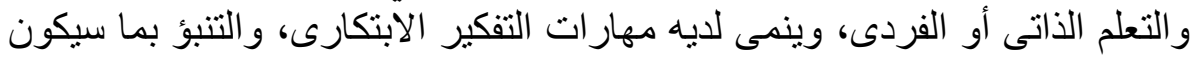

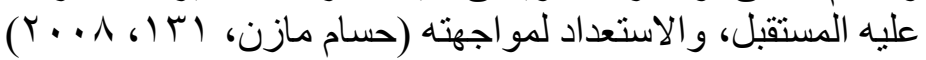

وفى إجابة "Cavanaugh, Cavanaugh" عن سؤال لماذا نستخدم الخيال العلمي فى تدريس العلوم؟ أكدا على أنه بيساعد على: - زيادة الميول العلمية لدى الطلاب وتطور ها. - تحسين اتجاهات الطلاب العلمية نحو العلوم الواقعية. - تتمية فهم الطلاب لعمليات العلم و العلاقة بين التخصصات العلمية المختلفة. - تعلم الطلاب موضوعات العلوم المتقدمة و المجردة، مثل: (الإشعاع- الطفراتالقيم- علم الصور ايخ..) و التي يصعب تقديم خبر ات عملية أو مباشرة فئها. 
- تحسين مو اقف التعلم الحقيقية وجعل العملية التعليمية مثيرة وممتعة للمتعلمين مما Cavanaugh, Cavanaugh, 2004, يسهل تذكر المعلومات التي درسوها

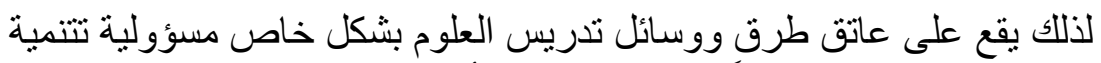

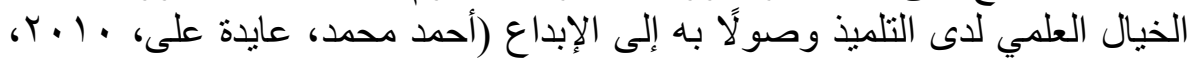
( IVT

هذا ما أكدته العديد من الدراسات والأدبيات التربوية على أهمية تضمين

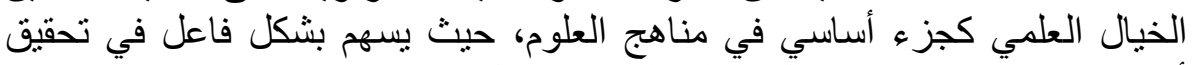

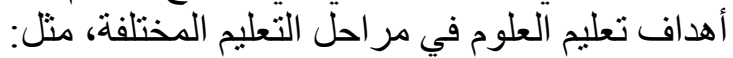

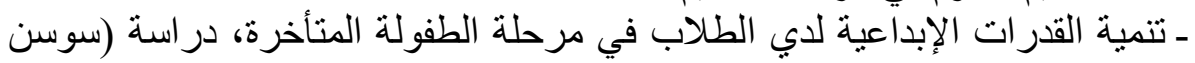

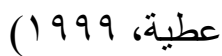
ـ تتمية التفكير الابتكاري لدى تلاميذ الصف الثاني الإعدادي، دراسة (سها الثافعى، (Y... - زيادة قدرة الطلاب المكفوفين على التخيل العلمي مما أدى إلى تغير اتجاهاتهم

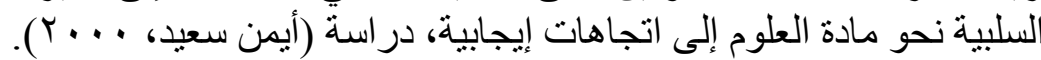

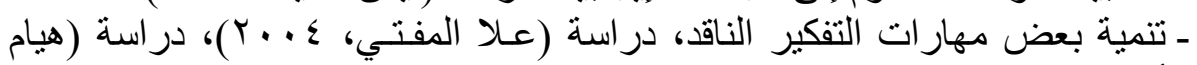

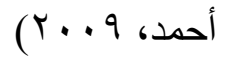

ـ تصحيح المفاهيم البديلة لدى الطلاب، دراسة (Ongel-Erdal, et.al, 2004)

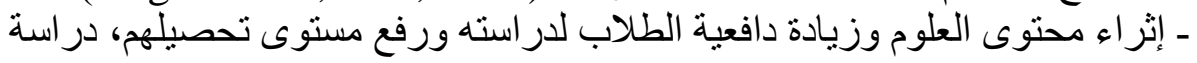
(Oravetz,2005) - يقلل الاتجاهات السلبية للطلاب غير المتخصصين في العلوم نحو مادة البيولوجي،

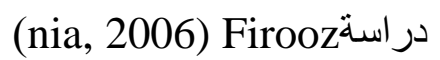
ـ له دور إيجابي في اتجاهات المراهقين نحو التخصد التحص في القسم العلمي بالثانوية

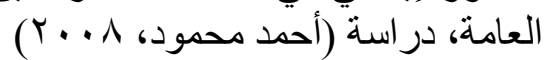

- رفع مستوى التتور لدى الطلاب، در اسة (Harrett; Benjamin, 2009) ـ ـمو مستوى الميول العلمية وفهم العلاقة بين العلم و التكنولوجيا لدى الطئ الطلاب، دراسة (Laprise, Winrich, 2010) - توضيح أثر العلم و التكنولوجيا على المجتمع دراسة (Zoreda, 2002) (Czerneda, 2010)

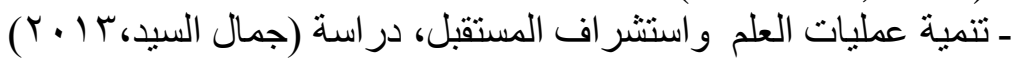

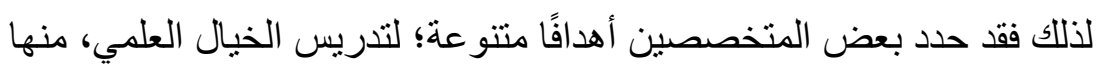

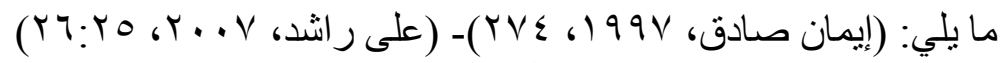

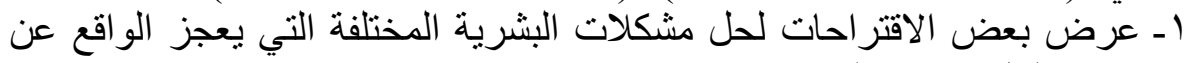
تقديم حلول مرضية لها بهن الاتيات 
r- تعليم الحقائق و المفاهيم العلمية بأسلوب مشوق وممتع ومثير بعيداً عن جفاء المعلومات في الكتب المدرسية.

r ـ حث الطلاب على التأمل و التفكير بمرونة.

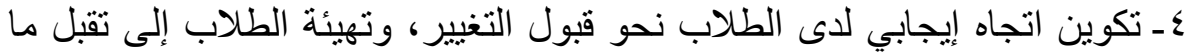
سيكون عليه العالم في المستقبل. الطبل

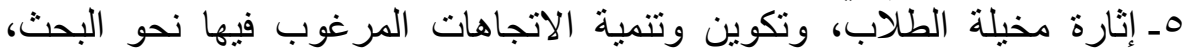
وفرض الفروض و اختبار صحتها، وتخيل عدة حلول متنتو عة للمشكلة الو احدة الطئ.

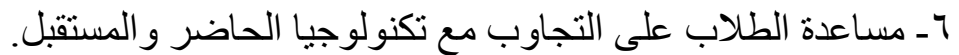

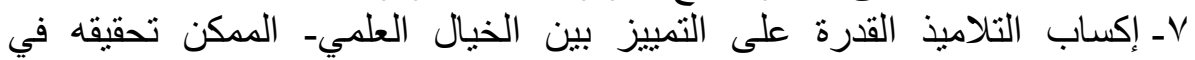

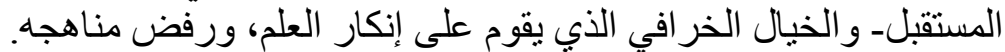

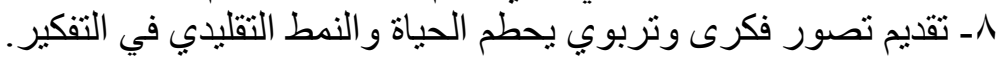
وبذلك يمكن أن نستخلص من هذا المحور : أن استخدام الخيال العلمي في إني

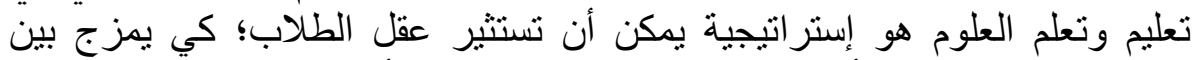

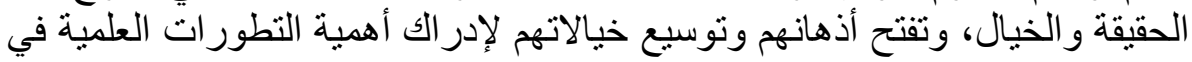

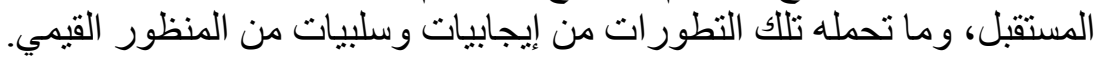

\section{خامسًا: كيفية توظيف الخيال العلمي في تدريس العلوم:}

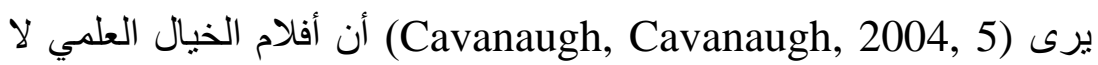
تستخدم بمفردها كطريقة لتدريس المفاهيم العلمية، ولكن يقترح طريقتين يمكن بهما توظيف الخيال العلمي في تدريس العلوم، هما:

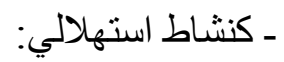

حيث يعرض الفيلم في بداية الدرس؛ ليعمل على إيجاد الميل المبدئي

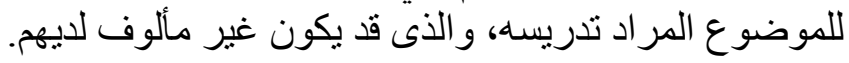

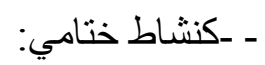

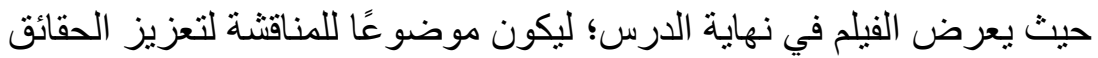

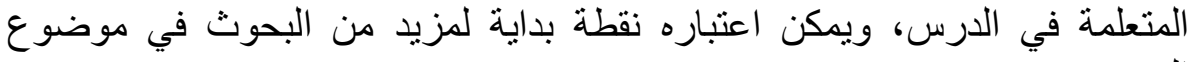

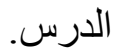

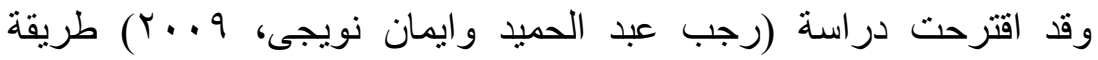
لتوظيف الخيال العلمي في التدريس تسير على النحو التالي:

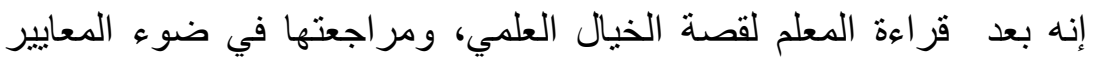

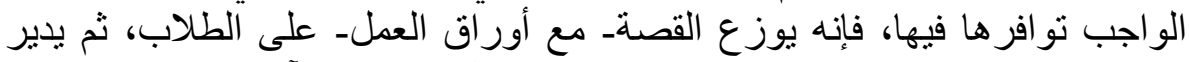

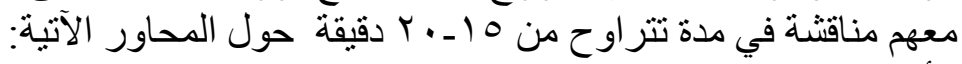

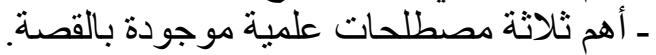
ـ دور العلم و العلماء في حل المشكلة الأساسية التي تدور حولهة الها أحداث القصة. 


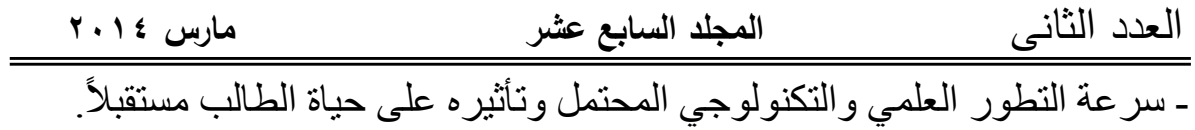

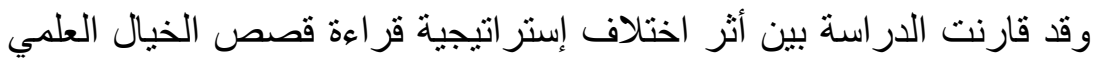

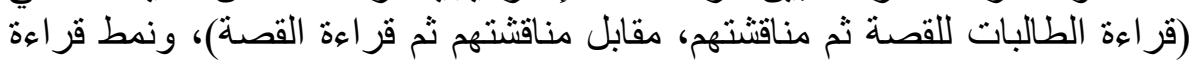

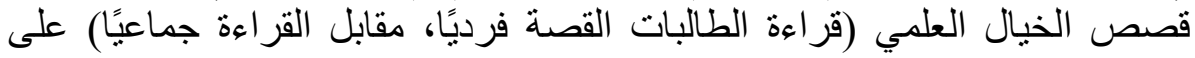
تتمية التخيل العلمي والاتجاه نحو الخيل العلمي.

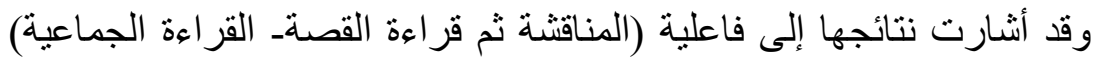

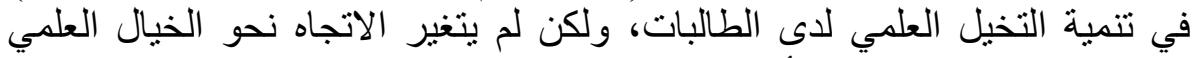

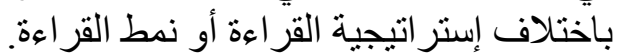

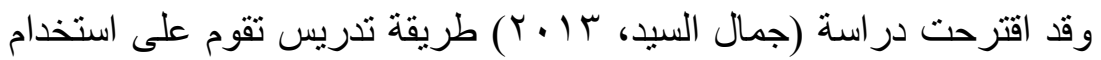

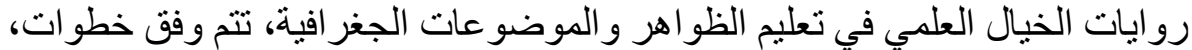

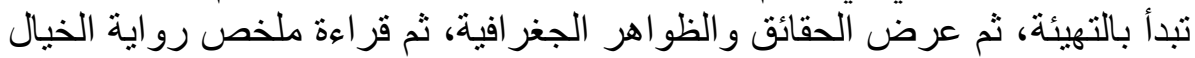

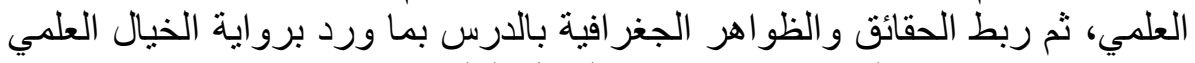

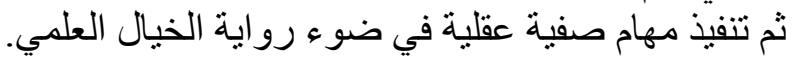

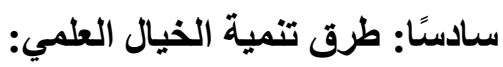

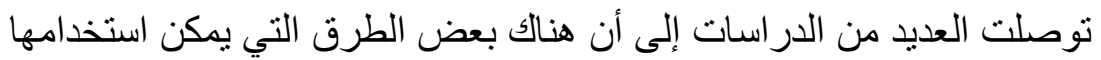
لتنمية الخيال العلمي لدى الطلاب، منها:

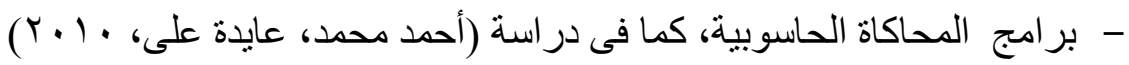

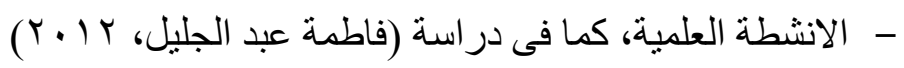

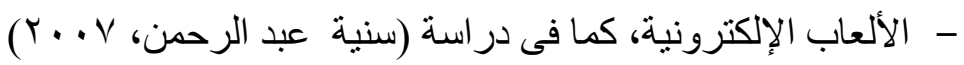

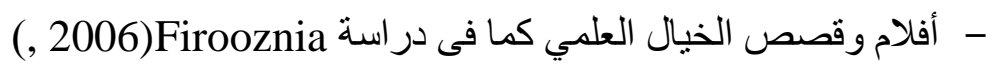
سابعًا: سلبيات الخيال العلمي وكيفية التظلب عليها:

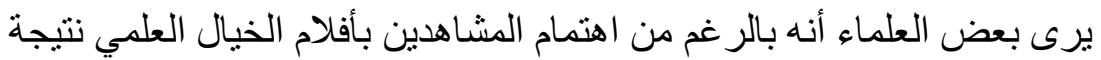

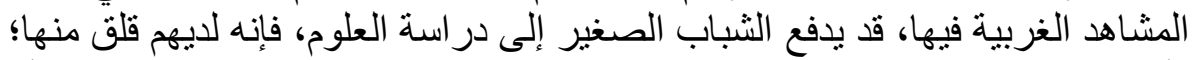

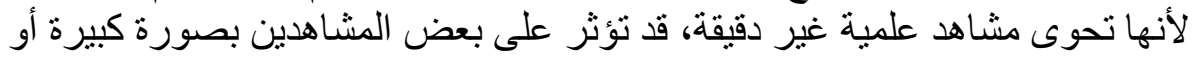

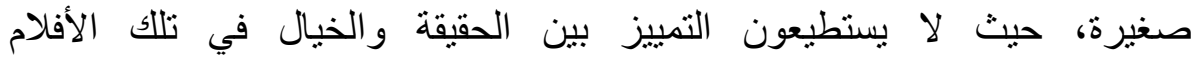

( Perkins, 2004,250)

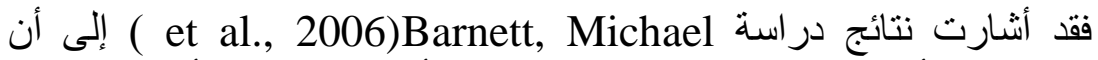

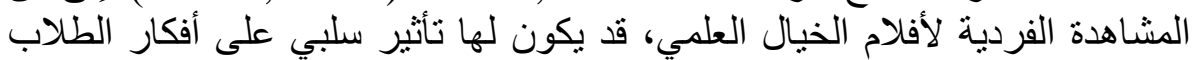

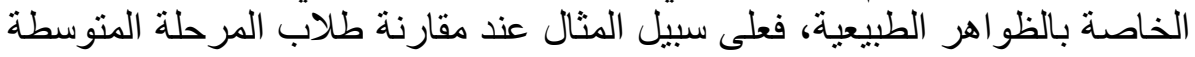

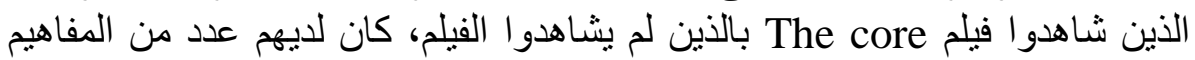

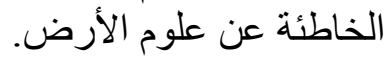

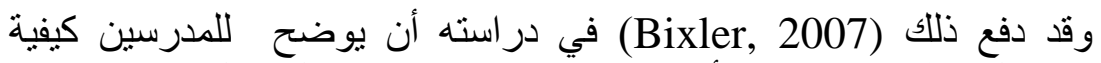
استخدام الخيال العلمي (قصص و أفلام) بطرق مختلفة في الفصل، منل: قر اءة القصة 


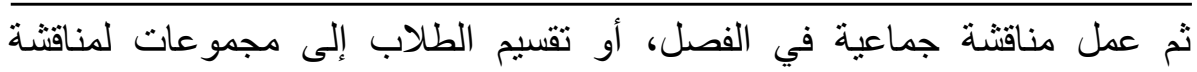

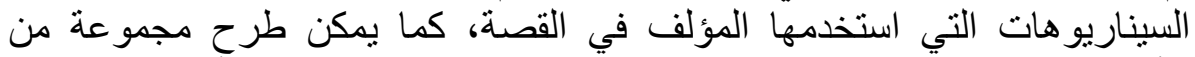

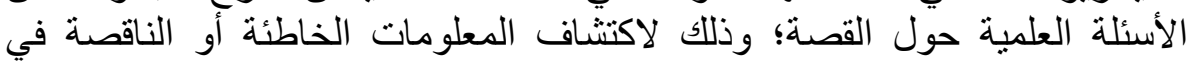

كما صممت دراسة (Laprise, Winrich, 2010) مهام مكتوبة في ثلاثة

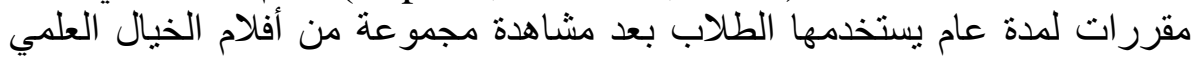
المختلفة؛ للقيام بنقدها من ناحية الدقة العلمية.

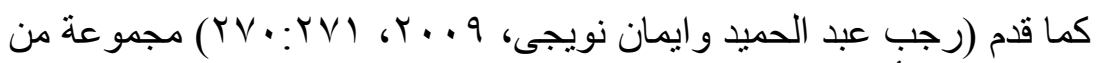
المعايير التي يجب أن يراعيها المعلم عند اختياره لقصص الخصا، الخيال العلمي الجيدة،

1 ـ تكون قائمة على حقائق علمية ثابتة تمتد وتستكمل عن طريق الخيال القائم على القى

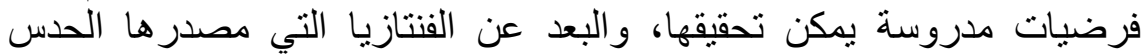
و التخمين و الخر افة وما شابه ذلك.

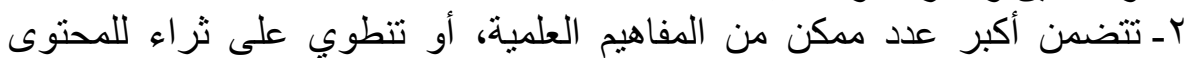

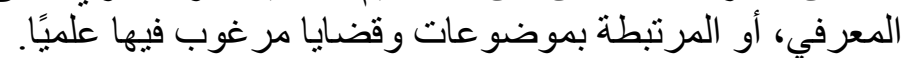

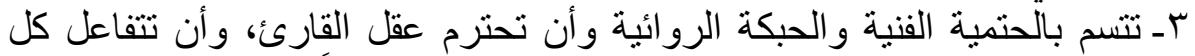

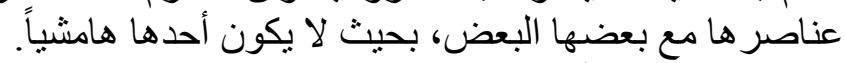
عـ تتميز ببساطة الأسلوب، وسلامة اللغة، وسهولة فهم المصنياً المطلحات العلمية

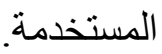

هـ تكون قائمة على أفكار العلم، ومنجز اته، وتصور اته، وأدق مسار اته.

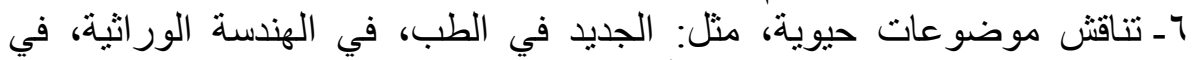

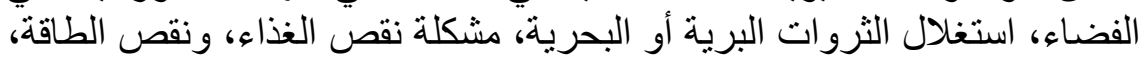

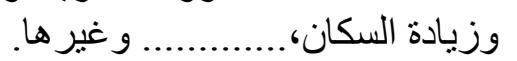

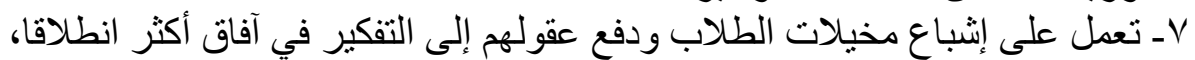

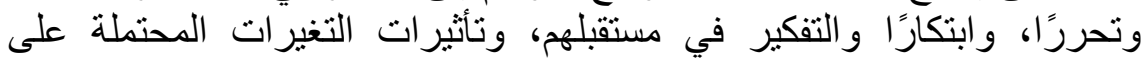

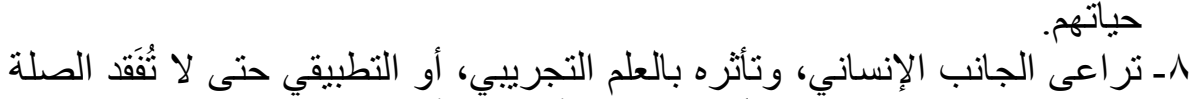

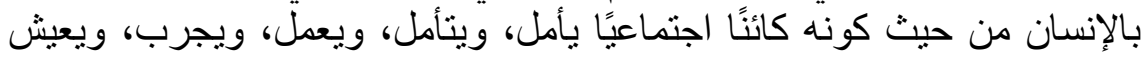
حياته بكل معطياتها. 9 ـ تكون ملائمة لفهم الطلاب المستهدفين، ومناسبة أيضًا لمحتوى الدروس المتعلمة

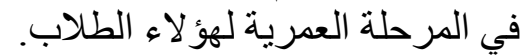

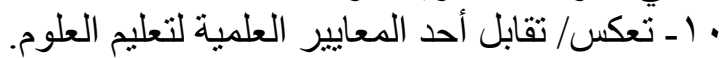

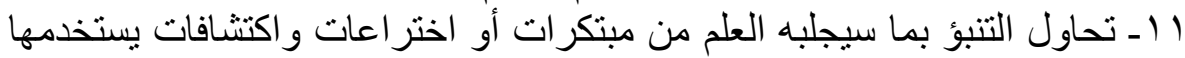
الإنسان مستقبلًا، أو تحذر من خطر محتمل مستقبلًا. r ا ـ تحث على تجنب التوظيف غير الخير لنتائج العلم و التقام العلمي.

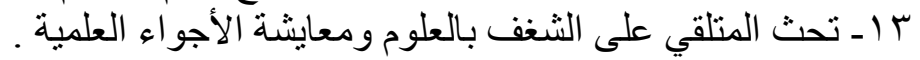




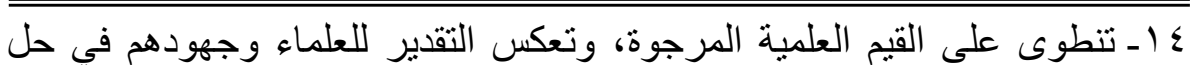
المشكلات بأسلوب على عليم لعطي.

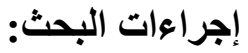

للإجابة عن تساؤلات البحث، والتأكد من صحة فروضه، سارت خطوات

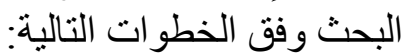

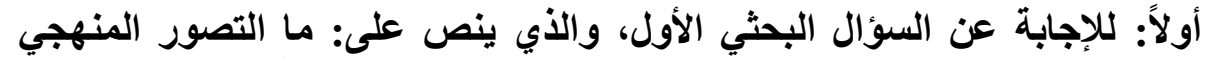

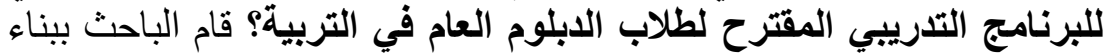

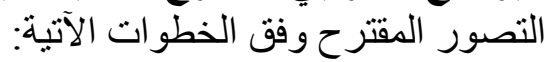
1 ـ تحديد أسس بناء التصور المقترح للبرنامج التدريبي: بيتند البرنامج الحالي إلى مجمو عة الأسس التالية:

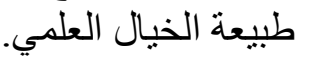
• أهداف تدريس العلوم بالتعليم العام.

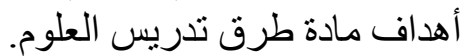

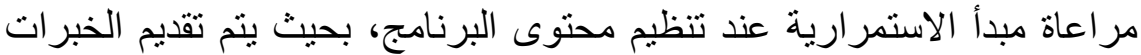

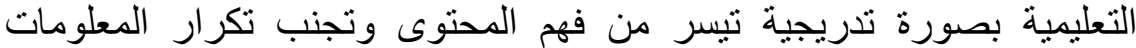

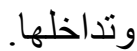
تنوع الأساليب والأنشطة التعليمية المتضمنة بمحتوى البرنامج؛ بحيث توفر بدائل

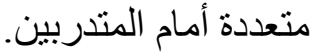

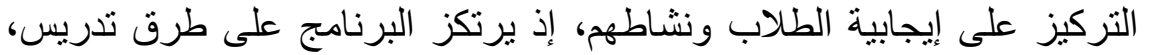

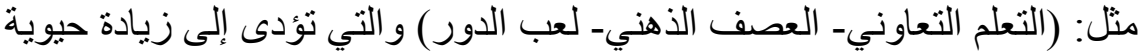

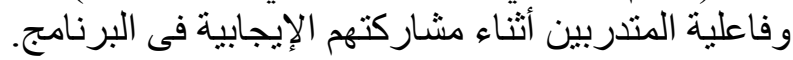

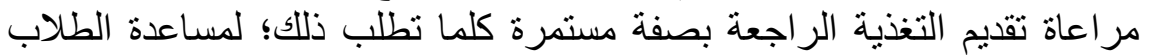

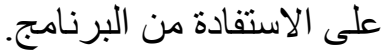
هر اعاة كيفية تطبيق برنامج الخيال العلمي في تدريس العلوم في التعليم العام . r ـ تحديد الهدف العام للبرنامج التدريبي المقترح :

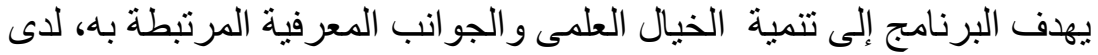
طلاب الدبلوم العام في التربية بعمادة خدمة المجتمع والتعليم المستمر بجامعة جازان. rـ تحديد الأهداف الإجرائية للبرنامج التدريبي المقترح: بانتهاء در اسة هذا البرنامج ينبغي على الطالب أن:

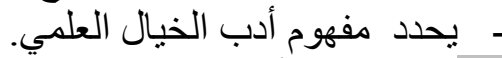
لمحدد سمات أدب الخيال العلمي. يتعرف على مر احل تطور أدب الخيال الخيال العلمي. يذكر بعض كتاب أدب الخيال العلمي. 
يتعرف على موضو عات قصص الخيال العلمي في وسائل الإعلام. - - - يتعرف على وسائل تقديم قصص على الخيال العلمي للأطفال.

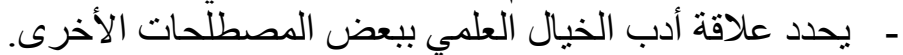
- - يحدد أهداف تدريس أدب الخيال العلمي.

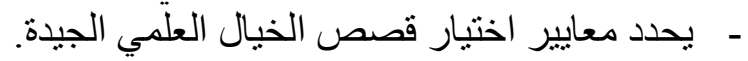

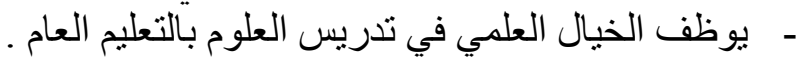

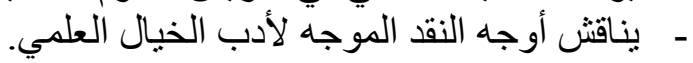
- - يقلم تصور ات ذهنية للنتائج المترتبة على الخيال أكتشافات يتخيل توصل الإنسان إليها

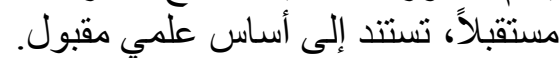

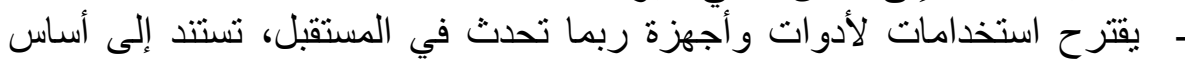
علمي مقبول.

ع ـ تحديد محتوى البرنامج التدريبي المقترح:

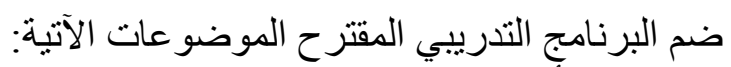

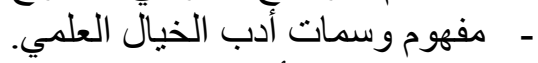
- مر - مراحل تطور أدب الخيال العلمي. - - - كتاب أدب الخيال العلمي الغربيين.

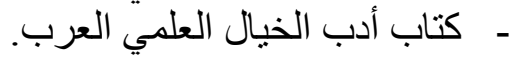
- - موضو عاب أب قصص الخيال العلمي في وسائل الإعلام. - مصص الخيال العلمي للأطفال.

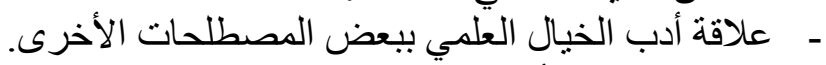

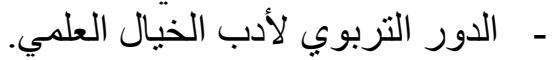

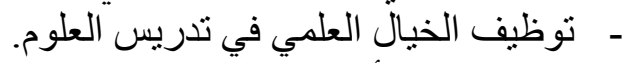

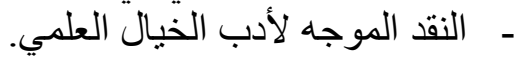

هـ الأنشطة المصاحبة للبرنامج:

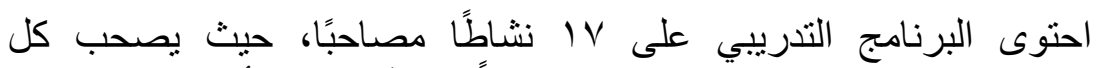

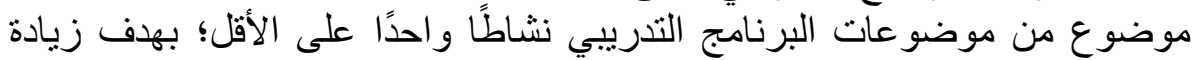

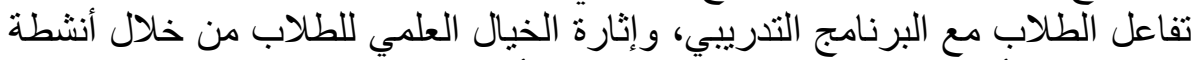

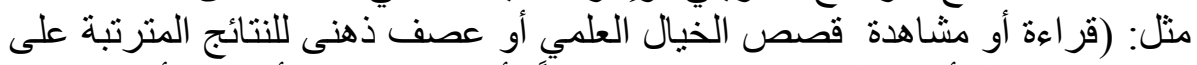

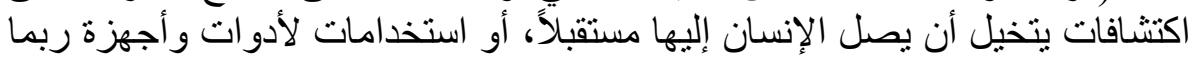
تحدث في المستقبل.............).

7- تحديد طرق التدريب المستخدمة بالبرنامج التدريبي:

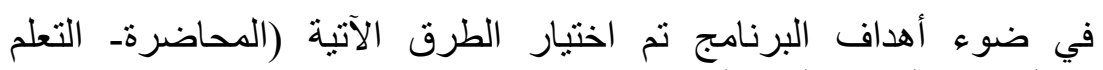

التعاوني- العصف الذهني- لعب الدور ). 
V- الخطة الزمنية اللازمة لتدريس البرنامج التدريبي:

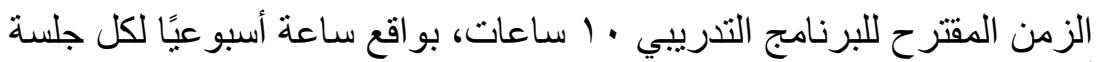

تتناول أحد موضو عات البرنامج التدريبي العشرة.

1ـ اختيار أسلوب تقويم الطلاب لمعرفة مدى تحقيقهم لأهداف البرنامج:

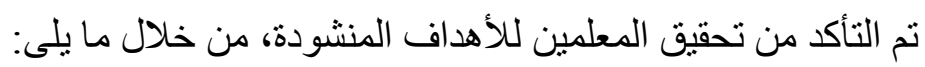

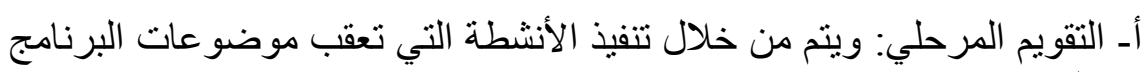

التدريبي.

بـ التقويم النهائي: ويتم من خلال تطبيق أدوات البحث بعديًا (الاختبار التحصيلي- اختبار الخيال العلمي).

9 - إعداد أدلة التدريب:

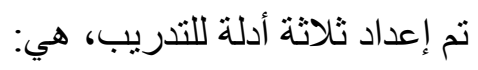

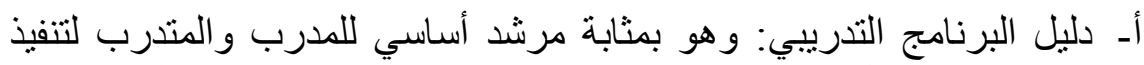

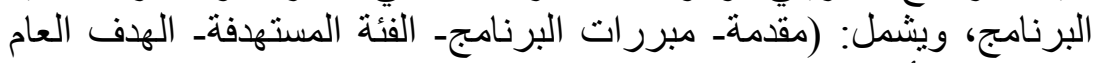

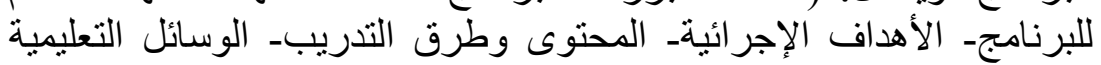

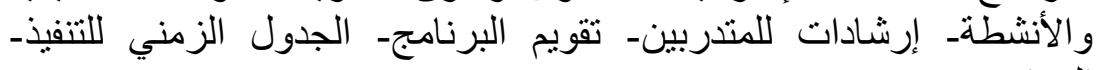
المر اجع).

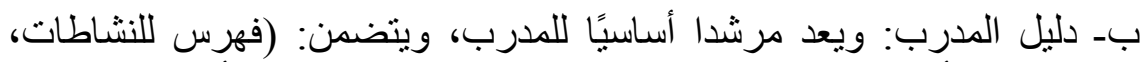

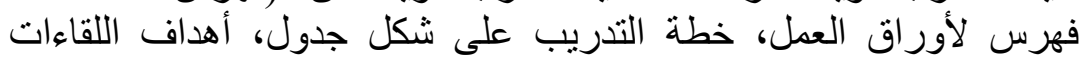

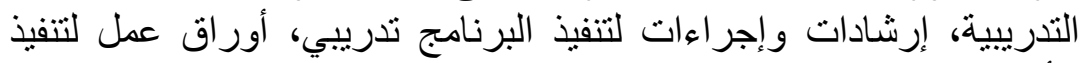
الأنشطة، تقويم البرنامج التندريبي).

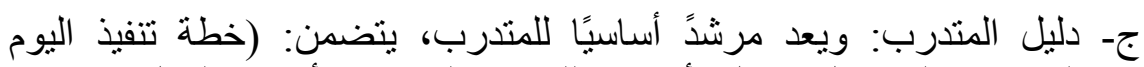

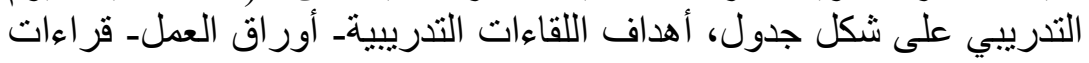

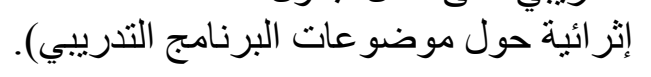
. 1 ـ صلاحية البرنامج التدريبي:

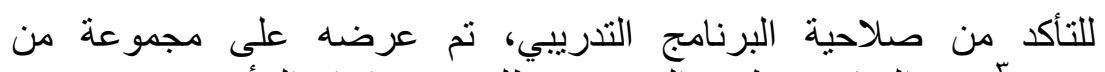

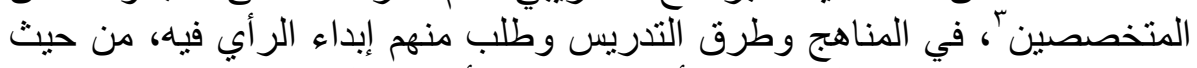

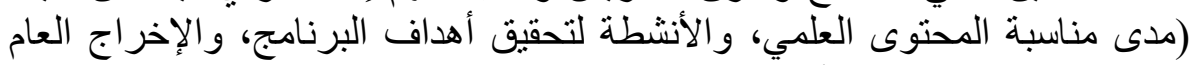

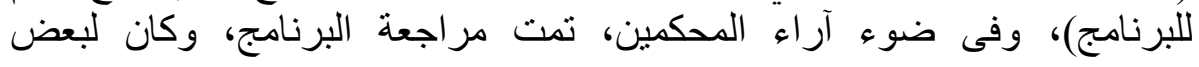

r ملحق (7) قائمة بأسماء السادة المحكمين على البحث في مر احله المختلفة.

مجلة التربية العلمية 
المحكمين آراء أخذت عند بناء البرنامج في صورته النهائية؛؛ وبذلك أصبح البرنامج التدريبي صالحًا للتطبيق. ثانيًا: للإجابة عن السؤال البحثي الثانى والذي ينص لثئي على: ما فاعلية البرنامج

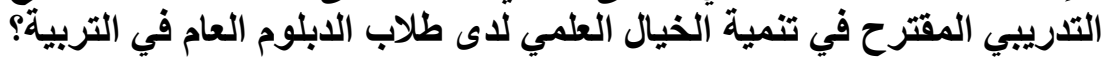
قام الباحث ببناء اختبار للخيال العلمي وفق الخطو التئي الت الآتية: 1 ـ تحديد الهذف من الاختبار:

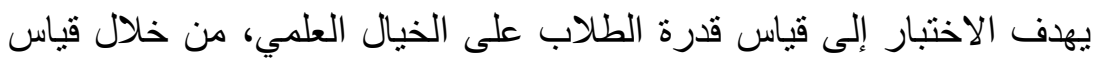

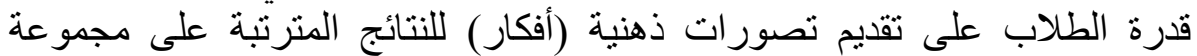

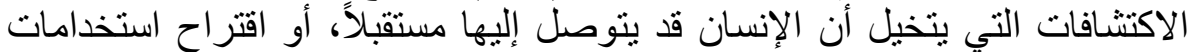

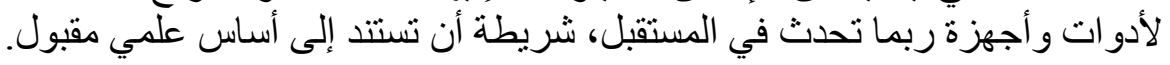

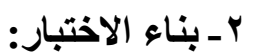

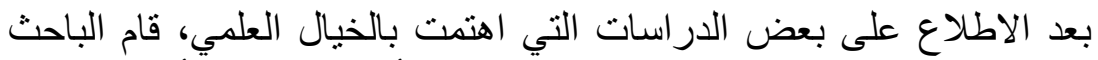

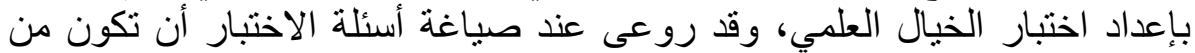

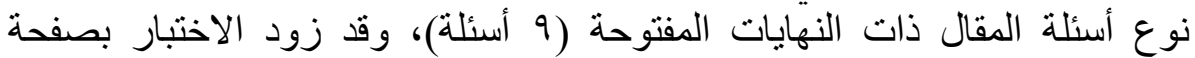

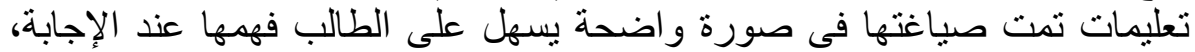

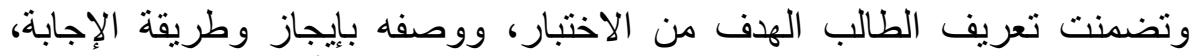
ومكان مخصص لكتابة بيانات الطالب، وتلى صفحة الإنئ التعليمات أسئلة الاختبار. rـ طريقة تصحيح الاختبار وتقدير الدرجات:

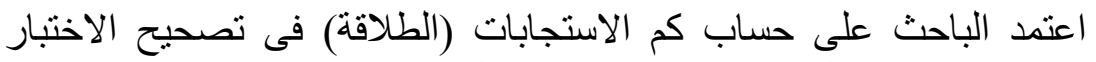

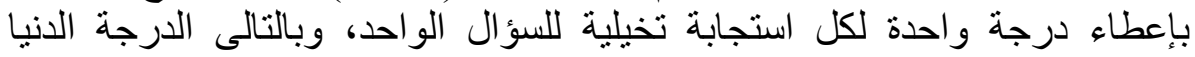
للاختبار هى صفر ، وتصبح الدرجة العليا للاختبار بدون تحديد لإل العيمة كمية.

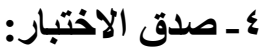

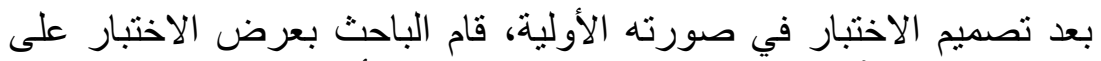

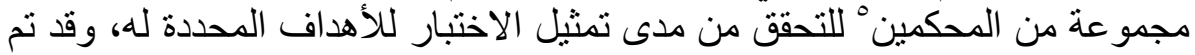

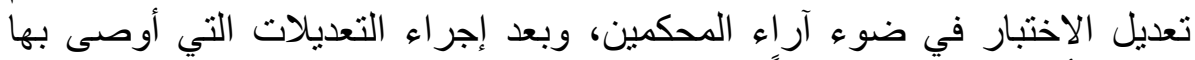
الخبر اء أصبح الاختبار ضئ ضعادقاً.

\section{هـ التجربة الاستطلاعية للاختبار:}

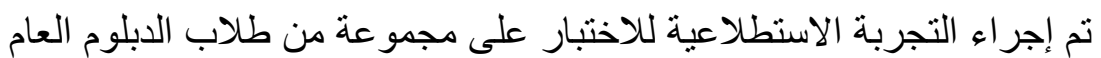

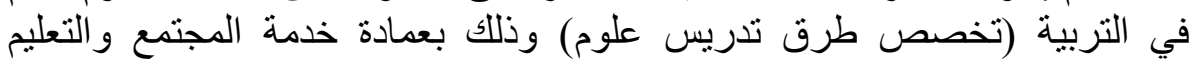
المستمر - جامعة جاز ان، بهدف التعرف على أسئلتهم واستفسار اتهم، وتحديد الزمن التعن 


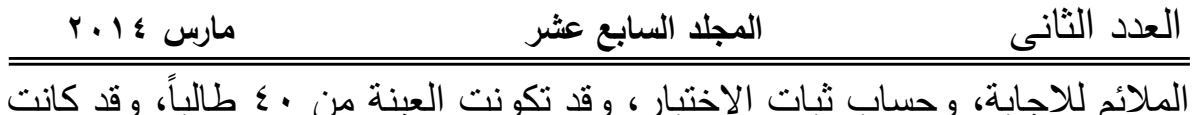
نتائج التجربة لإبة الاسنطلاعية كما يلي: أ- بالنسبة لوضوح الأسئلة:

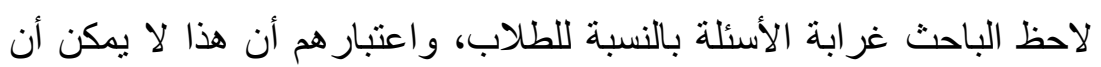
يحدث، وقد قام الباحث بتشجيع الطلاب وطلب الإب منهم كتابة ما يستطيعون. ب- بالنسبة لتحديد زمن الاختبار:

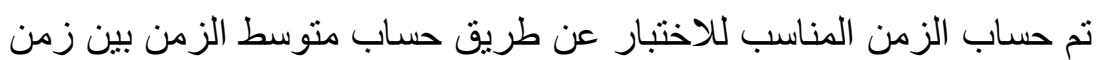

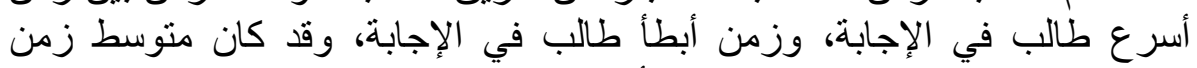

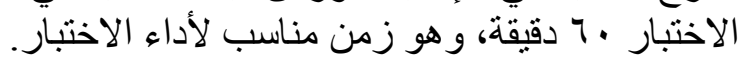

ج- بالنسبة لحساب ثبات الاختبار:

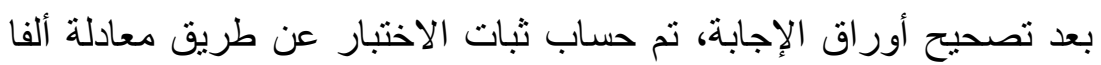

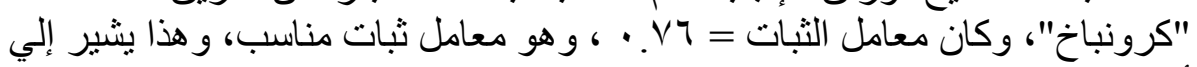
أن الاختبار يتمتع بدرجة ثبات معات مرتفعة، ويمكن الاعتماد عليه

\section{جـ الصورة النهائية للاختبار:}

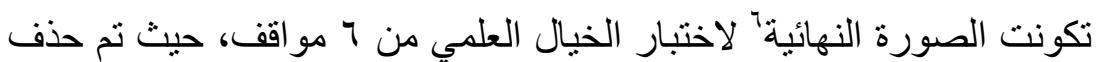

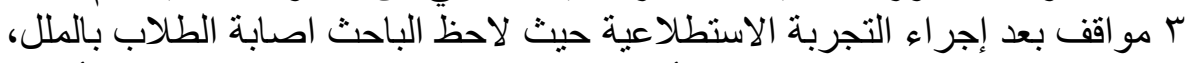

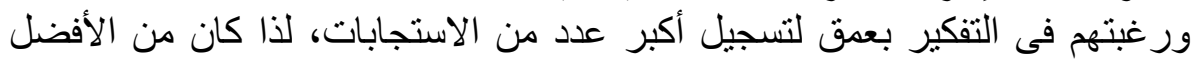

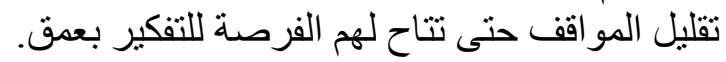

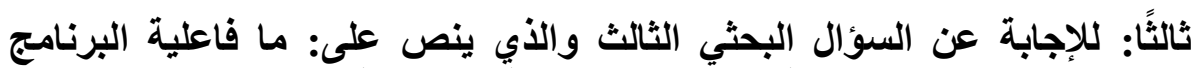

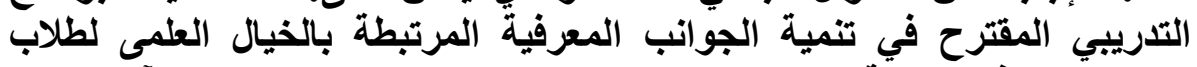

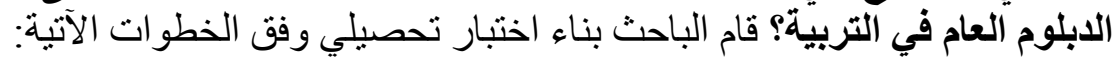

1 - تحديد الهذف من الاختبار:

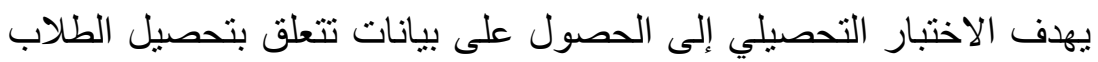

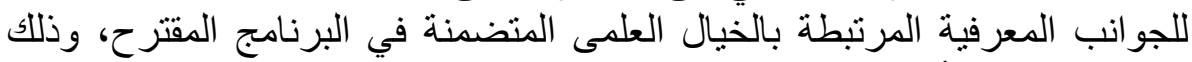

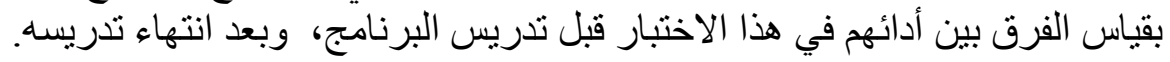
r - تحديد نوع الاختبار ومفرداته:

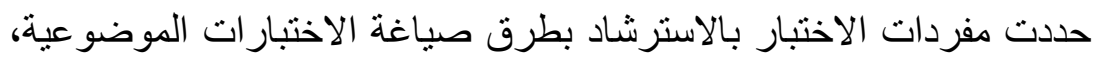

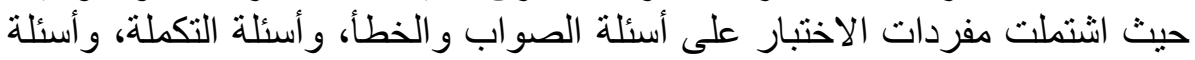

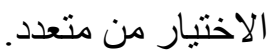

" ملحق (r) اختبار الخيال العلمي في صورته النهائية .

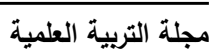




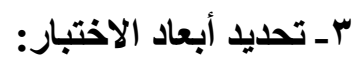

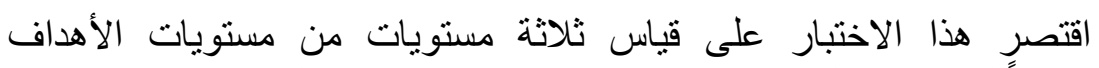
المعرفية وفقاً لتصنيف "بلوم" Bloom وهي: (التذكر، الفهم، التطبيق). ع ـ تحديد جدول المواصفات:

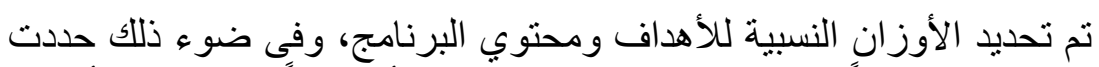

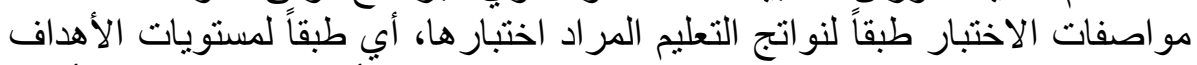

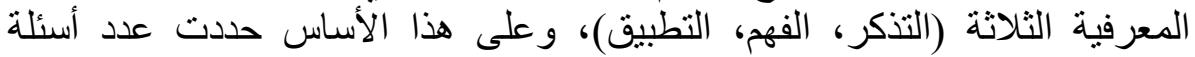

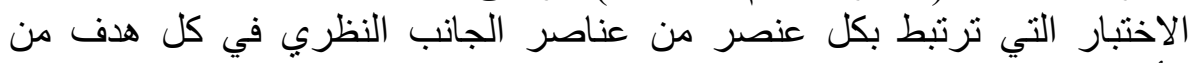

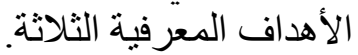

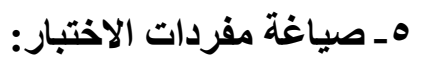

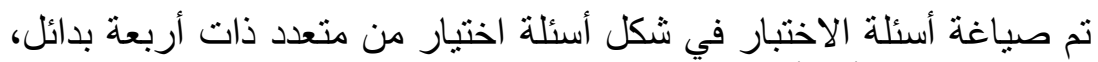

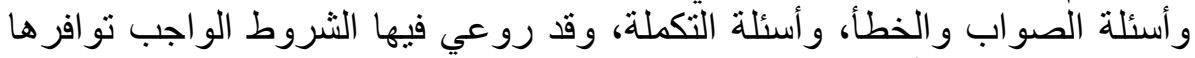
في هذا النوع من الأسئلة. 7- الصورة الأولية للاختبار:

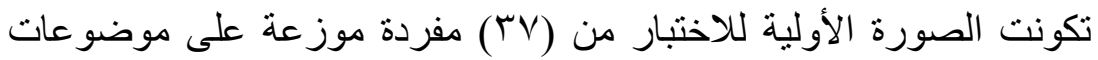

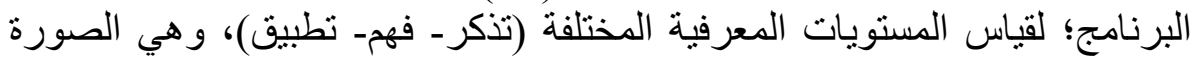
التي تم عرضها على المحكمين.

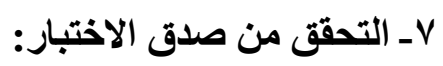

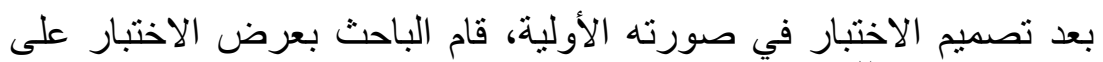

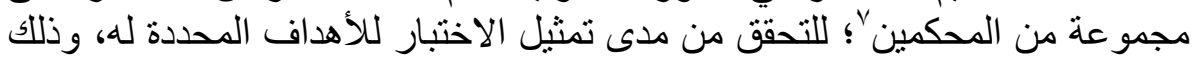

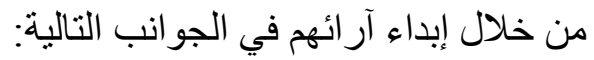

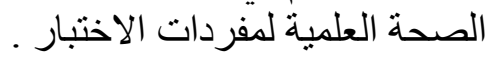

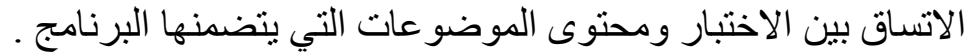
صلاحية كل مفردة لقياس تحصيل الطلاب على الإنى المستوى المعرفي المثنل لها.

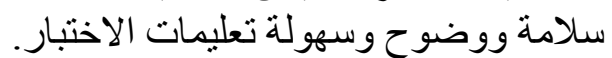

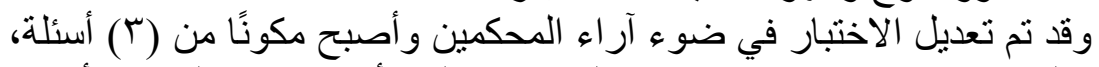

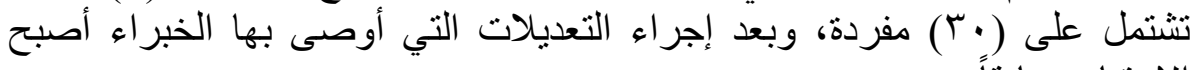
الاختبار صادقاً.

" ملحق (7) قائمة بأسماء السادة المحكمين على البحث في مر احله المختلفة

مجلة التربية العلمية 
^ـ إعداد ورقة الإجابة ومفتاح التصحيح:

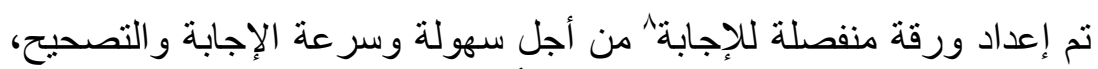

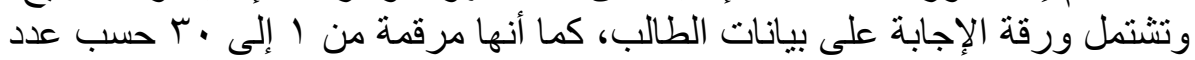

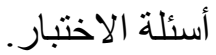
كما تم إعداد مفتاح تصحيحج لأسئلة الاختبار مما يؤدي إلى سهولة وسرعة تصحيح أوراق الإجابة. 9- إعداد تعليمات الاختبار:

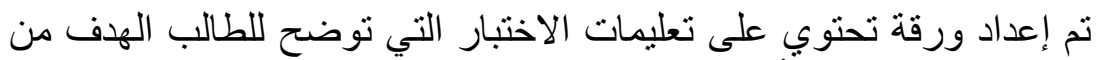
الاختبار ، وكيفية الإجابة عن أسئلة الاختبار باستخدام ورقة الإنة الإجابة المنفصلة.

• 1 ـ التجربة الاستطلاعية للاختبار:

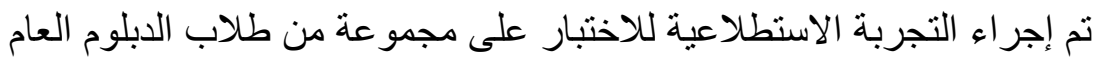

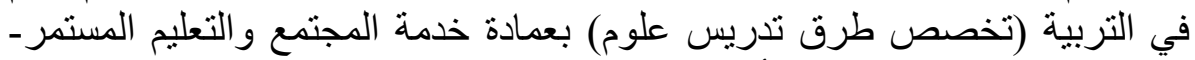

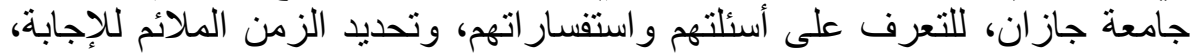

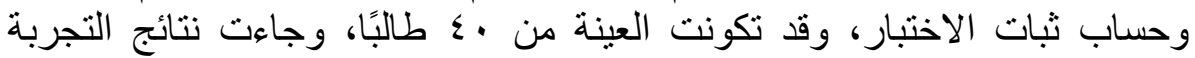
الاستطلاعية كما يلي: و الإنيار،

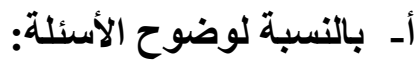

لاحظ الباحث غرابة الأسئلة الخاصة بكُة الابلة أدب الخيال العلمي عند الطلاب،

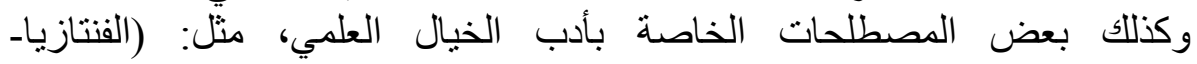
اليوتوبيا.......)؛ وذللك لعدم قر اعتهم في ذللك المجال.

\section{ب- بالنسبة لتحديد زمن الاختبار:}

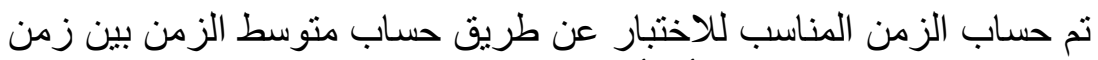

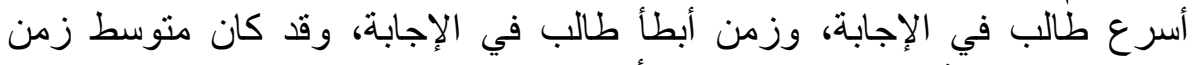

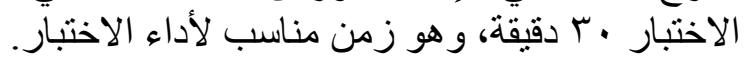

ج- بالنسبة لحساب ثبات الاختبار:

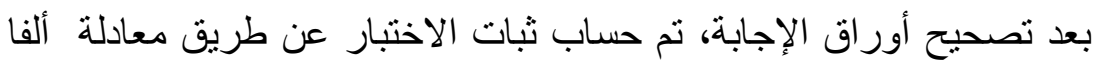

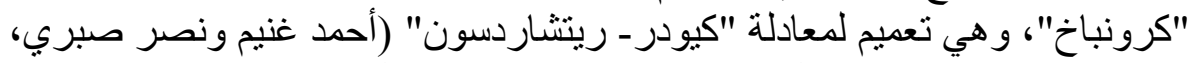

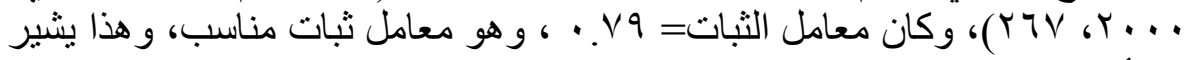

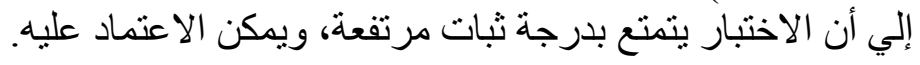

^ ملحق رقم (ع) ورقة الإجابة للاختبار التحصيلي. 9 ملحق رقم (0) مفتاح تصحيح الاختبار التحصيلي.

مجلة التربية العلمية 


\section{1 ـ الصورة النهائية للاختبار:}

تكونت الصورة النهائية للاختبار من · ب مفردة من نوع (الاختيار من متعدد

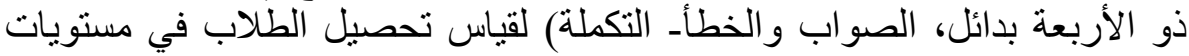
التذكر و الفهم و التطبيق، حيث يتم إعطاء درجة واحدة لكل إجابة صحيحة وصفر لكل

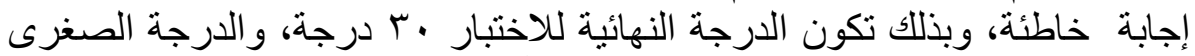
هي صفر، وبذللك أصبحت الصورة النهائية' للاختبار جاهزة للتطبيق، والبة والجدول التالي يوضي توزيع أسئلة الاختبار بمستوياتها المختلفة على موضو عات البرنامج. جدول (1) توزيع أسئلة الاختبار التحصيلي علي مستويات الأهداف التي يقيسها

\begin{tabular}{|c|c|c|c|c|}
\hline \multirow{2}{*}{ 子. } & \multicolumn{3}{|c|}{ 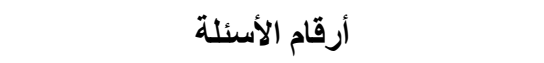 } & \multirow{2}{*}{ 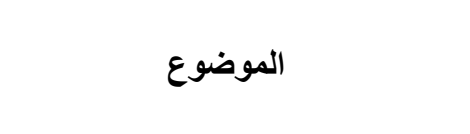 } \\
\hline & تطبيق & فهم & 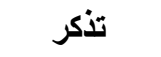 & \\
\hline$\varepsilon$ & - & $0, r$ & T. . TY & 1 - مفهوم وسمات أدب الخيال العلمي \\
\hline 1 & - & - & 1 & r- مر احل تطور أدب الخيال العلمي \\
\hline$r$ & - & - & r7. Y9 & r- كتاب أدب الخيال العلمي الغربيين \\
\hline$r$ & & & 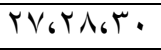 & ـ ـ كتاب أدب الخيال العلمي العرب \\
\hline$\varepsilon$ & - & - & $\begin{array}{l}17.9 \\
r \leq 619\end{array}$ & 0ـ فوضي وسائل الإعلام قصص الخيال العلمي \\
\hline 1 & - & - & TO & 7ـ قصص الخيال العلمي للأطفال \\
\hline 0 & - & - & $\begin{array}{l}1 r_{6} 11_{6} V \\
\mid \Lambda_{6} T_{1}\end{array}$ & V- المصطة أدب الخيال العلمي ببعض الأخرى \\
\hline 0 & - & 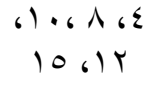 & - & مـ ـ الدور التربوى لأدب الخيال العلمي \\
\hline$r$ & $1 V_{6} 1 \sum_{6} 7$ & - & - & 9 - توظيف الخيال العلمي في تدريس \\
\hline r & - & r & YY & • 1 ـ النقد الموجه لأدب الخبال العلمي \\
\hline$r$. & $r$ & $\Lambda$ & 19 & \\
\hline$\% 1 \ldots$ & $\% 1$ & $\% Y V$ & $\% 74$ & المجموع \\
\hline
\end{tabular}

تتكون عينة البحث من طلاب الدبلوم العام فى التربية (تخصص علوم) بعمادة

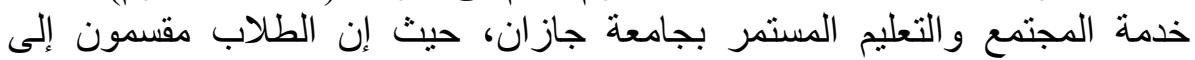
شعبتين كالآتي:

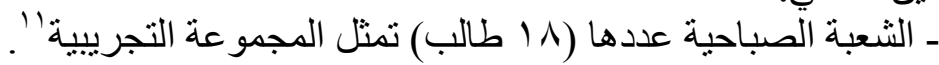
ـ الثعبة المسائية عددها (V V ل طالب) تمثل المجمو عة الضابطة. 
r - التطبيق القبلي لأدوات البحث:

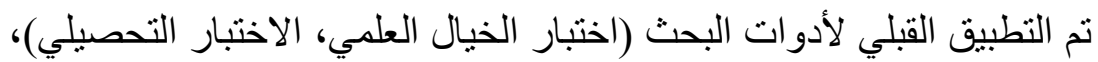

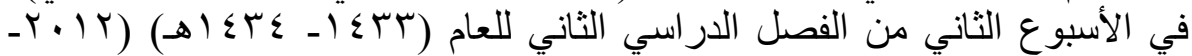

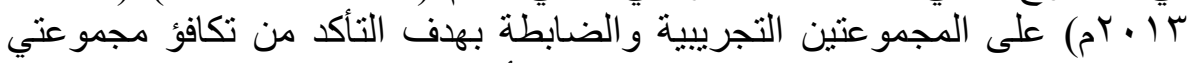
البحث، وقد تم استخدام اختبار "مان وتيني" للتأكد من تكافؤ المجمو عنين، فيما يلى لئى

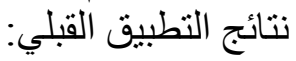

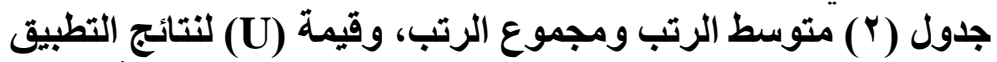

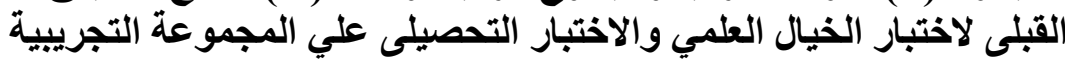
والضابطة

\begin{tabular}{|c|c|c|c|c|c|c|}
\hline \multirow{2}{*}{ الدلالة } & \multirow{2}{*}{ قيمة } & \multicolumn{2}{|c|}{ المجموعة الضابطة } & \multicolumn{2}{|c|}{ المجموعة التجريبية } & \multirow[t]{2}{*}{ المجموعة } \\
\hline & & مجموع & متوسط الرتب & مجموع & متوسط & \\
\hline غير دالة & $1 \cdot r$ & rov & YI & rVT & 10 & اختبار الخيال العلمي \\
\hline غير دالة & $|r| .0$ & rrV.0 & $r \cdot$ & Y9Y.0 & 17 & الاختبار التحصبلي \\
\hline
\end{tabular}

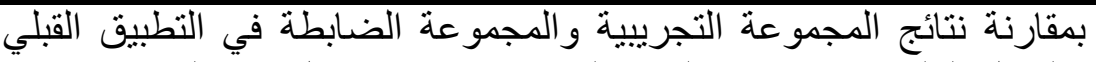

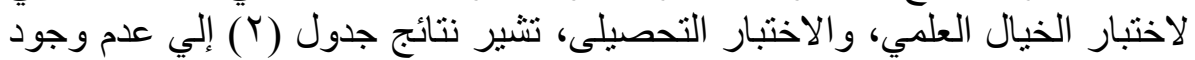

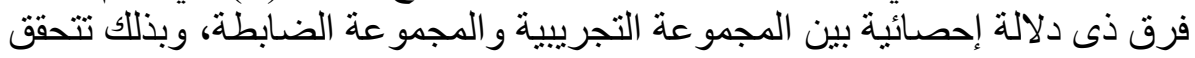

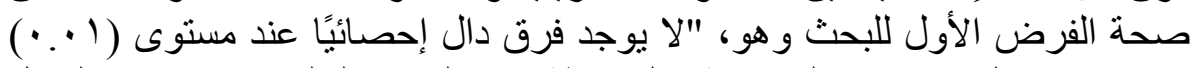

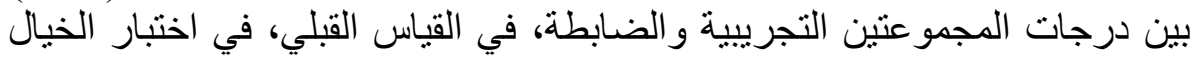

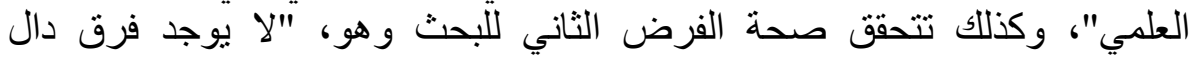

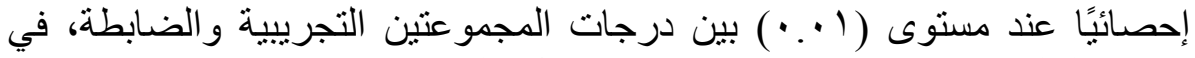
القياس القبلي، في الاختبار التحصيلي"، مما يدل على نلى تكافؤ المجمو عتين.

\section{بـ ت تطبيق البرنامج المقترح:}

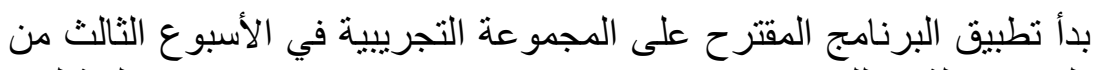

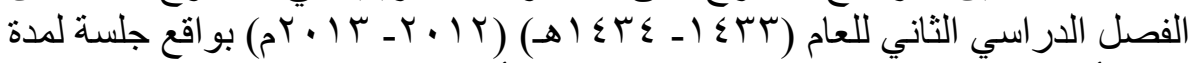

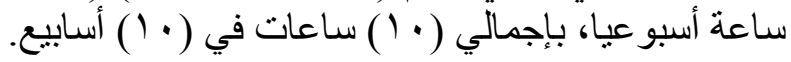

$$
\text { عـ التطبيق البعدي لأدوات البحث: }
$$

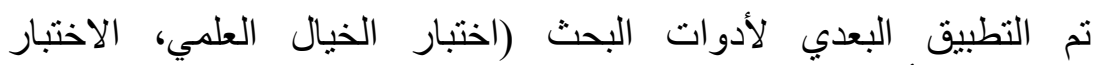

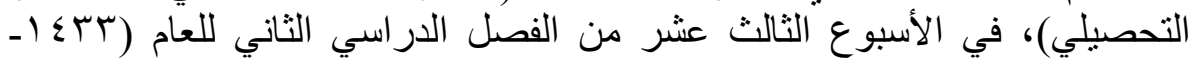

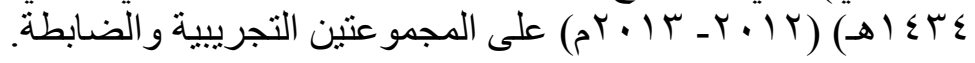
نتائج البحث:

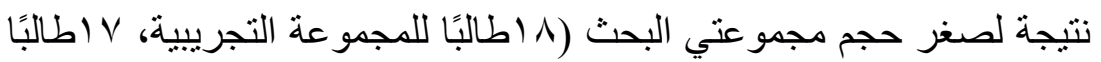
للمجمو عة الضابطة) استخدم الباحث للمعالجة الإحصائية للبيانات: 
- اختبار ويلكوكسون zilcoxon (z) ويعد هذا الاختبار الإحصائي هو الاختبار

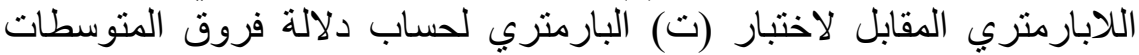

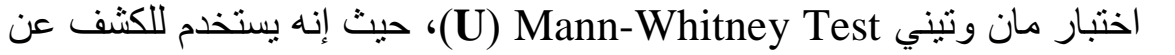

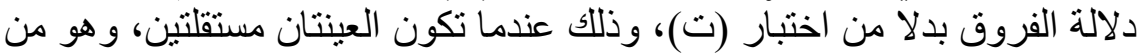

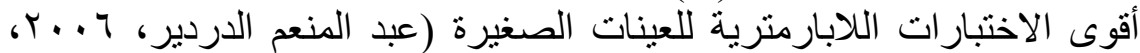

- حساب قوة العلاقة بين المتغيرين، المستقل (البرنامج التدريبي المقترح)، و التنابع

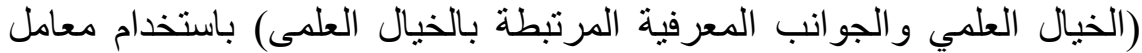

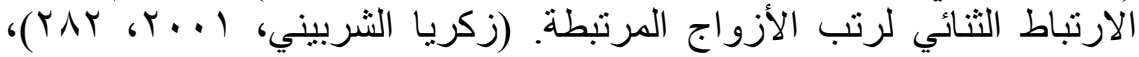

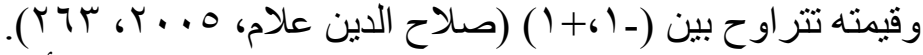

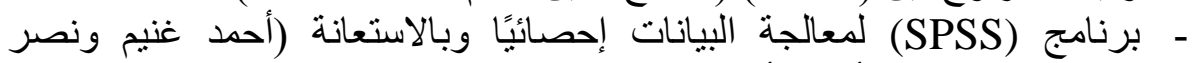

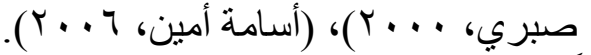

$$
\begin{aligned}
& \text { أولاً- نتائج اختبار الخيال العلمي: (المئ }
\end{aligned}
$$

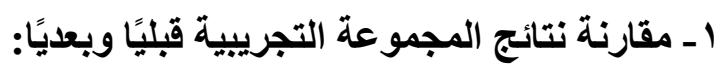

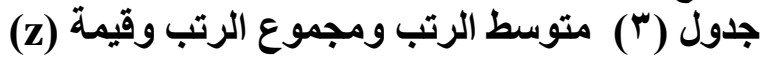

لنتائج التطبيق القبلي والبعدي لاختبار الخيال العلمي علي المجموعة التبونة التجريبية

\begin{tabular}{|c|c|c|c|c|}
\hline مستوى الدلالة & قيمة z & مجموع الرتب & متوسط الرتب & نوع الرتب \\
\hline \multirow{2}{*}{ دالة عند 1 •.. } & \multirow{2}{*}{$r . V$} & صفر & صفر & الرتب السالبة \\
\hline & & $1 V 1$ & 9.0 & الرتب الموجبة \\
\hline
\end{tabular}

بمقارنة نتائج المجموعة التجريبية في التطبيق القبلي و التطبيق البعدي لاخئ إختبار

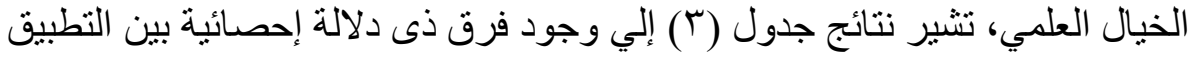

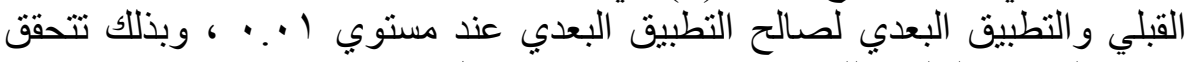

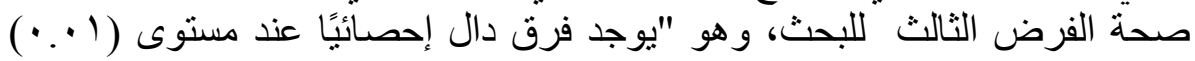

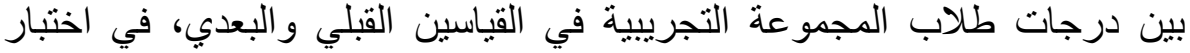
الخيال العلمي لصالح التطبيق البعدي". Y ـ مقارنة نتائج مجموعتي البحث (التجريبية الضابطة) بعديًا:

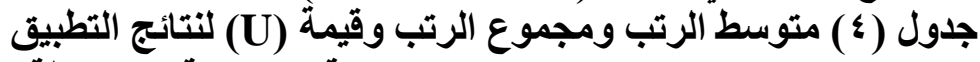

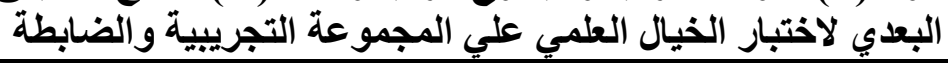

\begin{tabular}{|c|c|c|c|c|c|}
\hline \multirow{2}{*}{ الدلالةِ } & \multirow{2}{*}{ قيمة } & \multicolumn{2}{|c|}{ المجمو عة الضابطة ( ن = V V ) } & \multicolumn{2}{|c|}{ المجموعة التجريبية (ن = / ) } \\
\hline & & مجموع الرتب & متوسط الرتب & مجموع الرتب & متوسط الرتب \\
\hline دالة . & .0 & 104.0 & 9 & $\leqslant \vee 4.0$ & YY \\
\hline
\end{tabular}


بمقارنة نتائج المجموعة التجريبية و المجموعة الضابطة في التطبيق البعدي

لاختبار الخيال العلمي، تشير نتائج جدول (ع) إلي وجود فرق ذى دلالة إحصائية بين

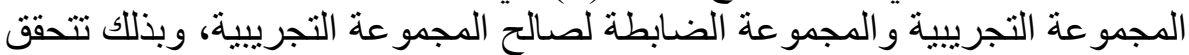
صحة الفرض الرابع للبحث وهو: "يوجد فرق دال إحصائيًا عند مستوى (1 ( . •) بين درجات المجموعتين التجريبية والضابطة، في القياس البعدى، في اختبار الخيال العلمي لصالح المجمو عة التجريبية.

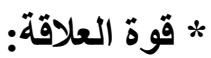

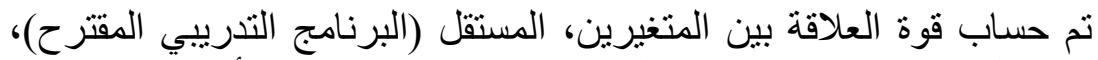

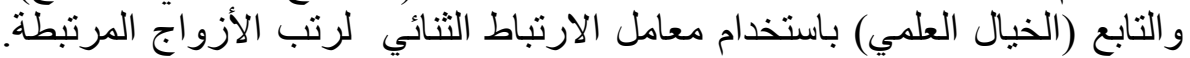

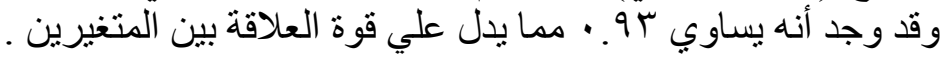

ثانيًا ـ نتائج الاختبار التحصيلي:

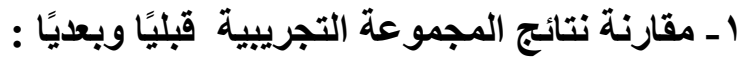

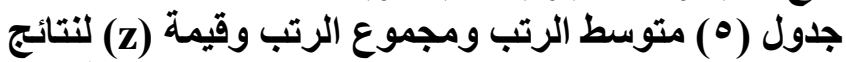

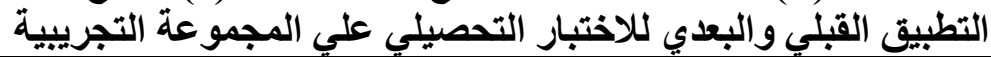

\begin{tabular}{|c|c|c|c|c|}
\hline مستوي الدلالة & قيمة ق & مجموع الرتب & منوسط الرتب & نوع الرتب \\
\hline \multirow{2}{*}{ دالة عند ا • . } & \multirow{2}{*}{$r . V$} & 1 & 1 & الرتب السالبة \\
\hline & & iv. & 1. & الرتب الموجبة \\
\hline
\end{tabular}

بمقارنة نتائج المجموعة التجريبية في التطبيق القبلي والتطبيق البعدي للاختبار التحصيلي، تشير نتائج جدول (0) إلي وجود فرق ذي دلالة إحصائية عند

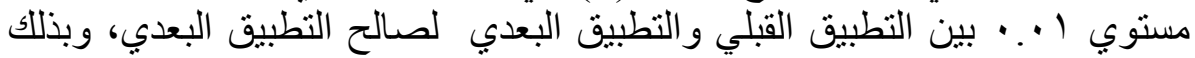

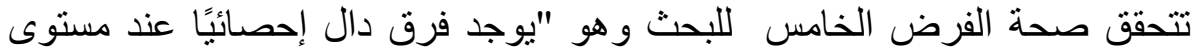

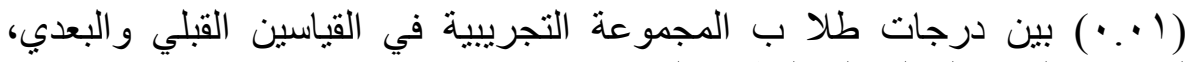
للاختبار التحصيلي لصالح التطبيق البعدي". r ـ مقارنة نتائج مجموعتي البحث (التجريبية الضابطة) بعديًا:

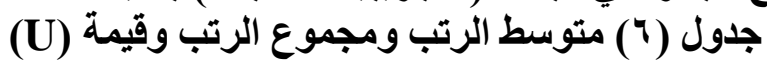

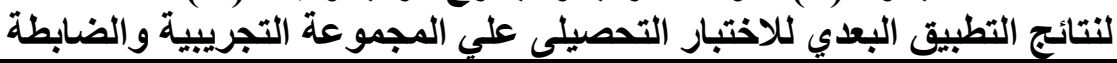

\begin{tabular}{|c|c|c|c|c|c|}
\hline \multirow[t]{2}{*}{ مستوى الدلالة } & \multirow{2}{*}{ قيمة U } & \multicolumn{2}{|c|}{ المجموعة الضنابطة ( ن = l ) ) } & \multicolumn{2}{|c|}{ المجموعة التجريبية (ن = ^ ( ) } \\
\hline & & مجموع الرتب & متوسط الرتب & مجموع الرتب & متوسط الرتب \\
\hline دالة عند I •. & 11 & $17 \varepsilon$ & $9 . V$ & $\sum 77$ & rT \\
\hline
\end{tabular}

بمقارنة نتائج المجموعة التجريبية و المجموعة الضابطة في التطبيق البعدي للاختبار التحصيلى، تشير نتائج جدول (T) إلي وجود فرق ذي دلالة إحصائية بين 
المجموعة التجريبية و المجموعة الضابطة لصالح المجمو عة التجريبية، وبذلك تتحقق صحة الفرض السادس للبحث، و هو: "يوجد فرق دال إحصائيًا عند مستوى (1 ( . • ) بين درجات المجموعتين التجريبية والضابطة، في القياس البعدي، في الاختبار التحصيلي لصالح المجمو عة التجريبية.

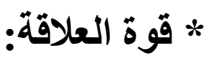

تم حساب قوة العلاقة بين المتغيرين، المستقل (البرنامج التدريبي المقترح)،

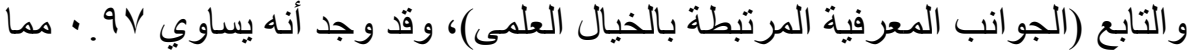
يدل علي قوة العلاقة بين المتغيرين. ثالثًاـ مناقشة النتائج وتفسيرها:

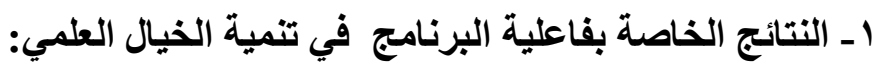

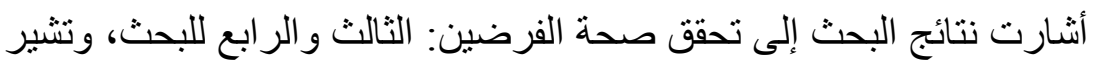

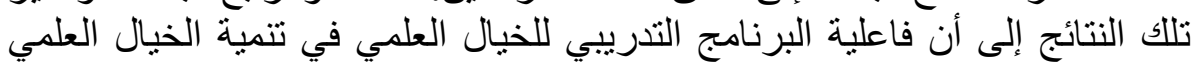
لدي طلاب المجمو عة التجريبية.

فقد أوضحت نتائج اختبار ويلكوكسون z ( ) Wilcoxon ) أن النمو في الخيال

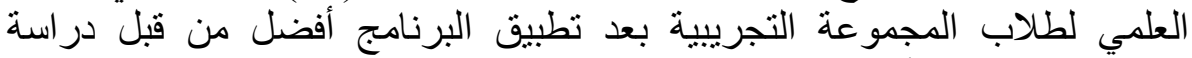

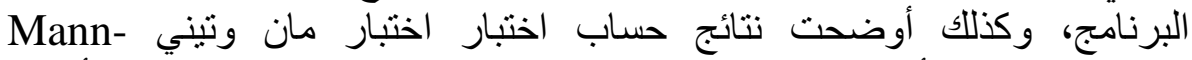
Whitney Test

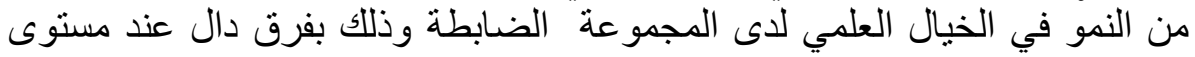
.$(\cdot \cdot 1)$

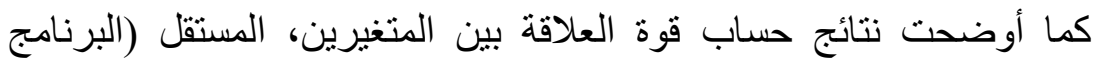
التدريبي المقترح)، والتابع (الخيال العلمي) باستخدام معامل الارنباط الثين الثنائي لرتب الرنب

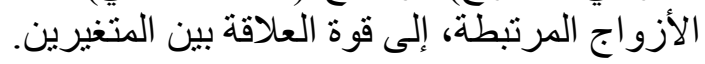

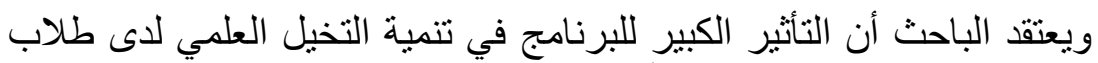

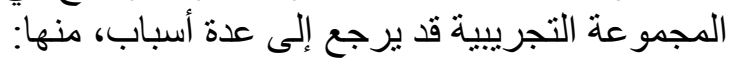

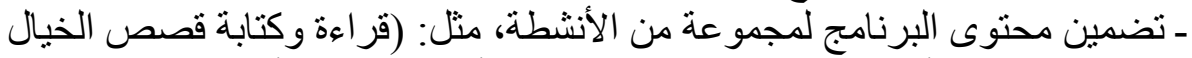
العلمي- مشاهدة أفلام خيال علمي ..............)، أدى إلى إثارة أفكار الخيال العلمي

ـ إتاحة الفرصة للطلاب للتعبير عن أفكارهم وتخيلاتهم كتابيا من خلال استكمال

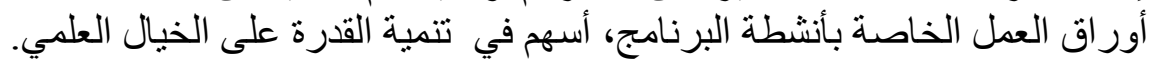

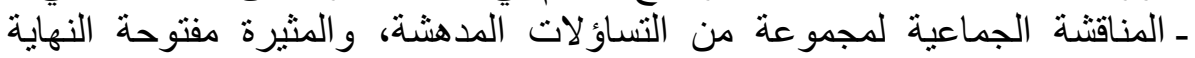

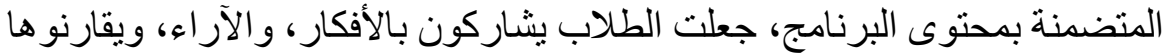
مع بعضهم البعض، مما ساعد على إنثارة تخيلات الطنات الطلاب العلمية.

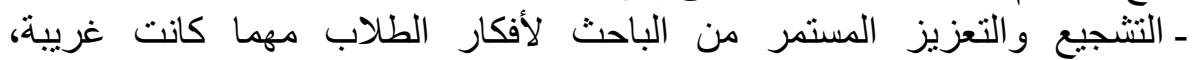
ومناقتنها، ساعد فى نمو القدرة على الخيال العلمي. لألئ 
وتتفق تلك النتائج مع نتائج الدراسات التي أوضحت إمكانية تنمية الخيال

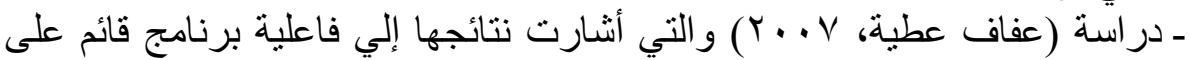
إسراع النمو المعرفي في علوم الفضاء في تنمية الخيال العلمي لدى تلاميذ المرحلة

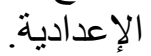

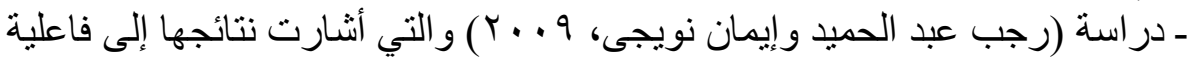
إستراتيجية قراءة قصص الخيال العلمي (المناقثة ثم قراءة القصة القئـ القراءة

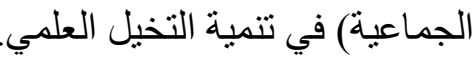

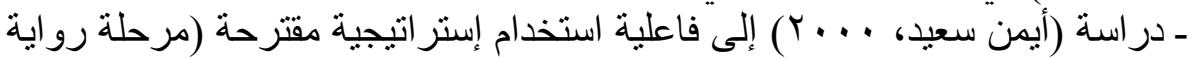

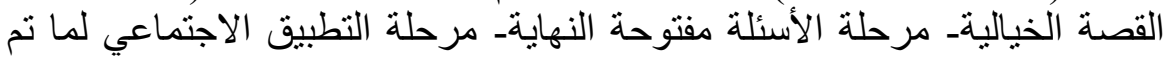

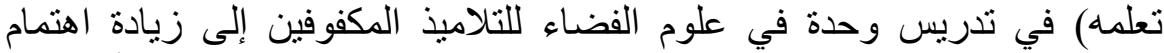

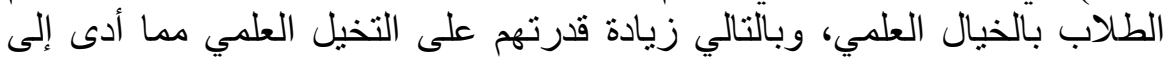

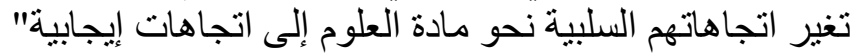

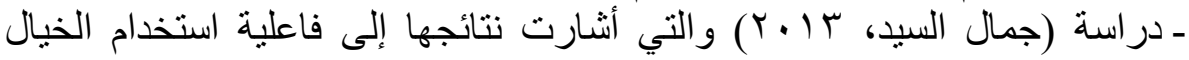

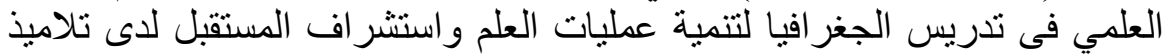
الصف الأول الإعدادي.

\section{النتائج الخاصة بفاعلية البرنامج في تنمية الجوانب المعرفية المرتبطة}

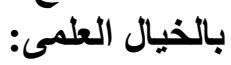

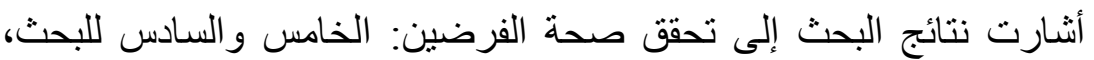
وتتير تللك النتيجة إلى أن در اسة البرنامج التدريبي المقترح أدت إلى تلى تنمية الجوانب الني

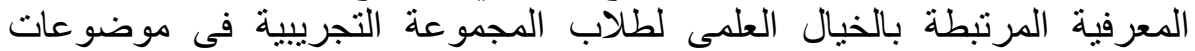

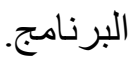

فقد أوضحت نتائج اختبار ويلكوكسون z ( ) Wilcoxon ) أن النمو في الجانب

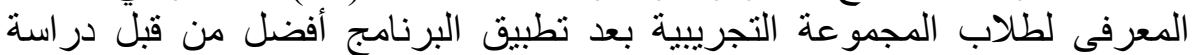
البرنامج، وكذلك حساب اختبار مان وتيني Mann-Whitney Test أن النيف النمو في في

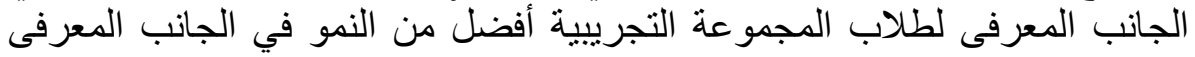
لطلاب المجموعة الضابطة وذلك بفرق دال عند مستوى ل .. .

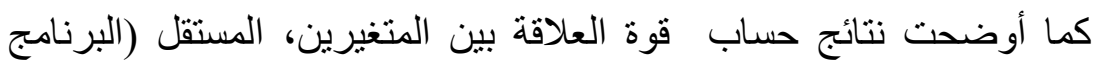

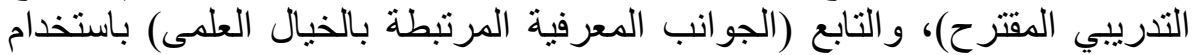

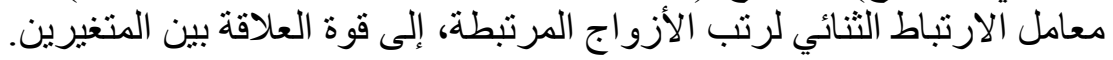

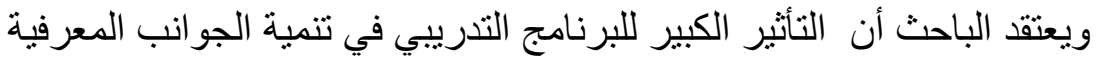

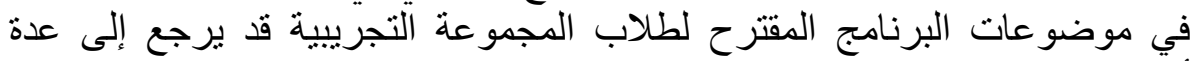
أسباب، منها:

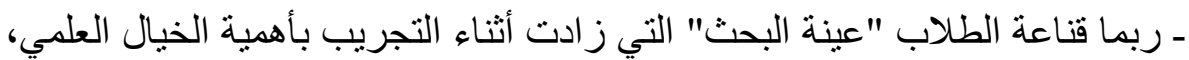

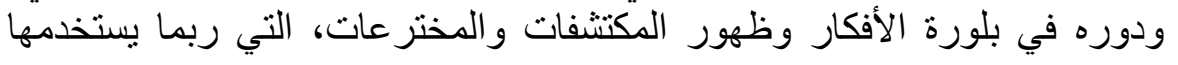


الإنسان مستقبلاً، وتحذيره من الأخطار المحتملة فى المستقبل، قد أدى إلى اهتمامهرج

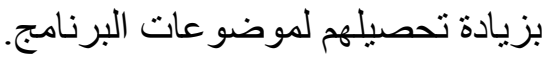

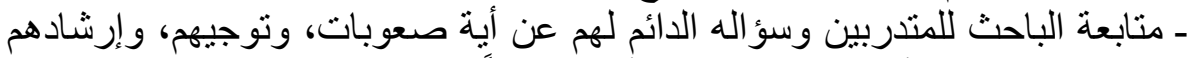

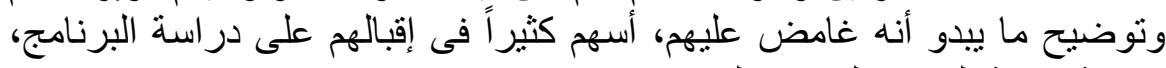

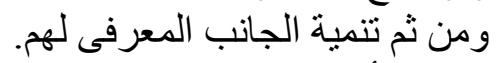

ـ تنوع الأنشطة و المواد التعليمية المقدمة في البران البرنامج التدريبي، أدى إلى تفاعل

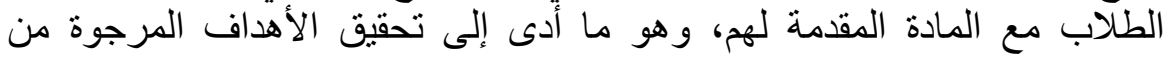
ـ التنويع في طرق التنريس التسيتخدمة، مثل: (المحاضرة- التعلم التعاوني- العصف

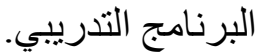

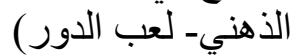
ـ استخدام كافة الإمكانات المتوافرة من وسائل تعليمية وتكنولوجية منطورة في

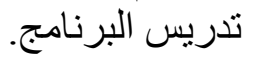

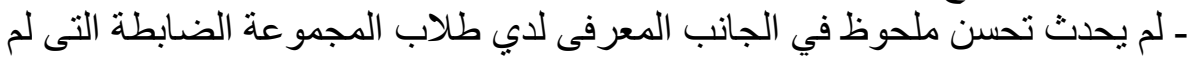

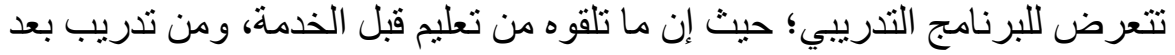

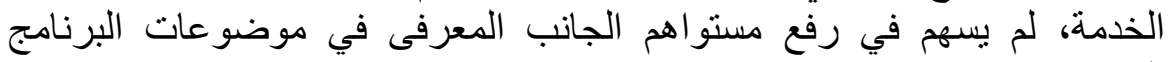
المقترح.

\section{تعليق عام على نتائج البحث:}

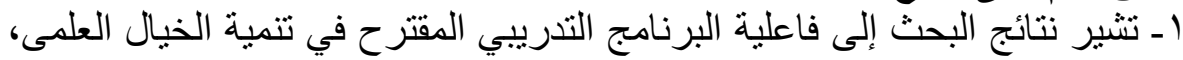

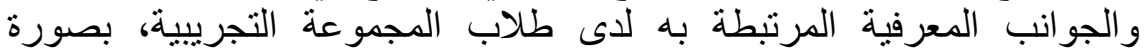

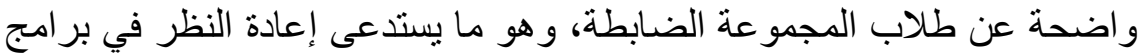

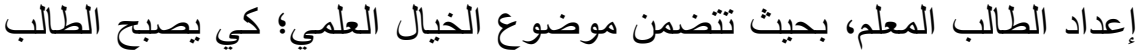
المعلم قادرًا على توظيفه في تدريس العلوم، وبالتالي تتحقق فو ائد استخدام الخيال

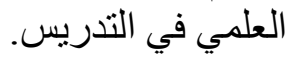
r ـ حاول الباحث من خلال هذا البحث أن ينمى الجو انب المعرفية للطلاب في الخيال

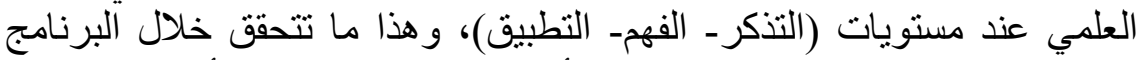

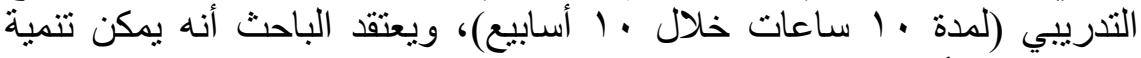

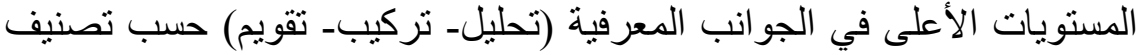

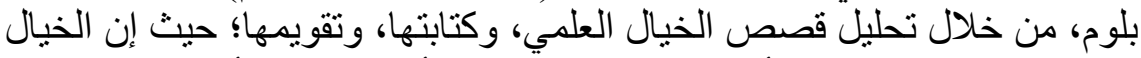

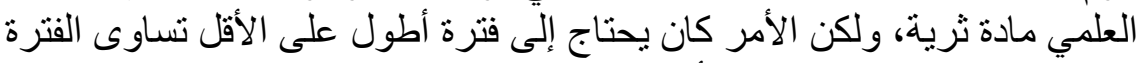

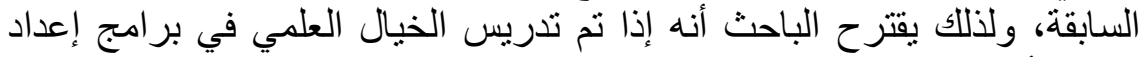

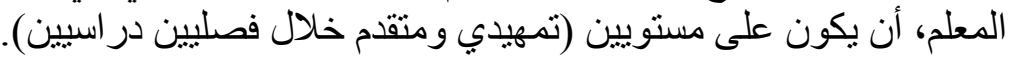

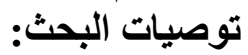

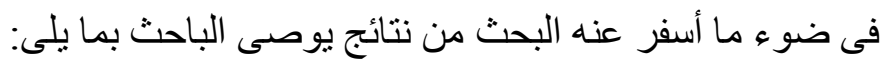

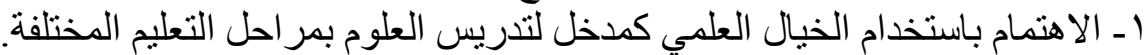

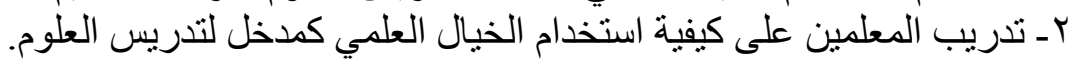


rـ توفير الإمكانات المادية بالمؤسسات التعليمية المختلفة والتي تساعد على ممارسة

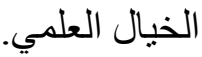

ع ـ إعادة صياغة كتب العلوم بحيث تتضمن بعض نوف نواحي الخيال العلمي، والتي

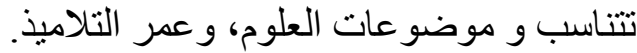

هـ تطوير دليل معلم العلوم بحيث يتضمن إعلير إرشادات حول كيفية تنفيذ الدروس باستخدام مدخل الخيال العلمي.

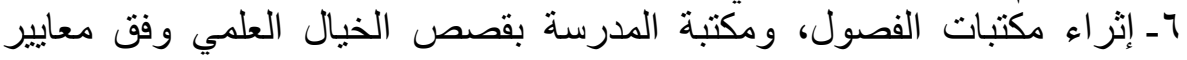
محددة؛ لاستخدامها في تعليم العلوم وتعلمها.

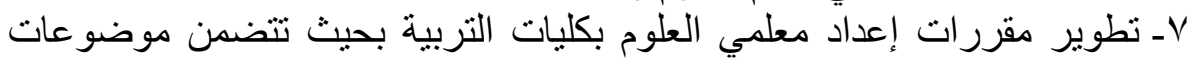
الخيال العلمي.

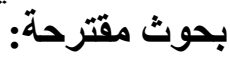

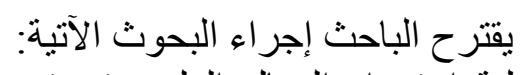

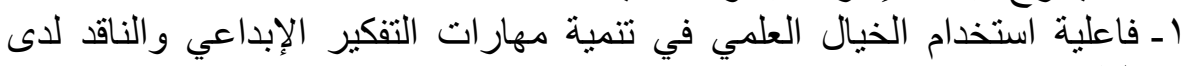

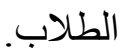

r ـ فاعلية استخدام الخبال العلمي في تتمية التفكير المستقبلي لدى الطلاب.

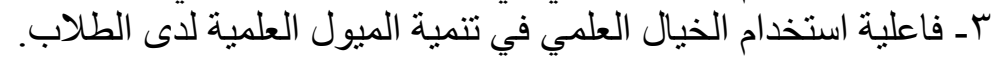

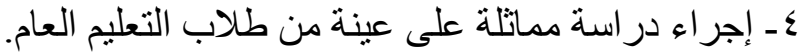

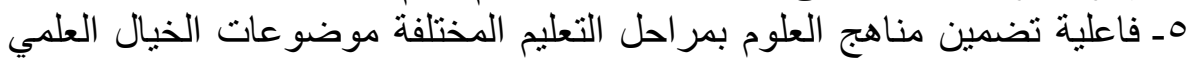

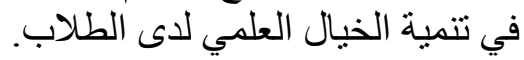

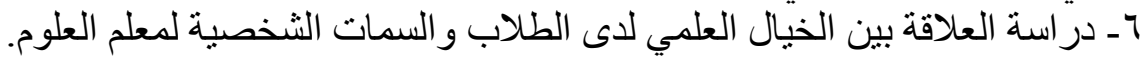

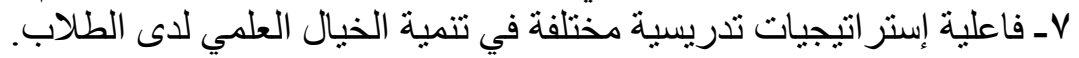

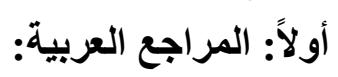

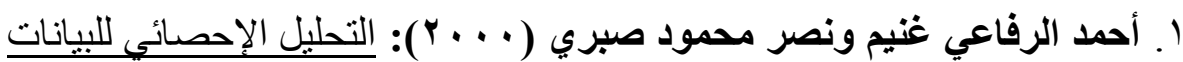

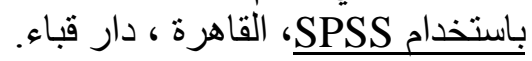

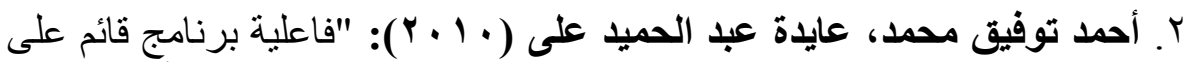

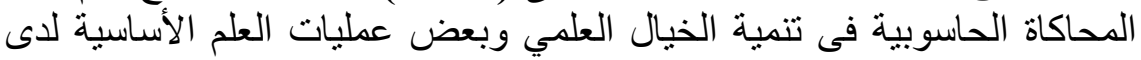

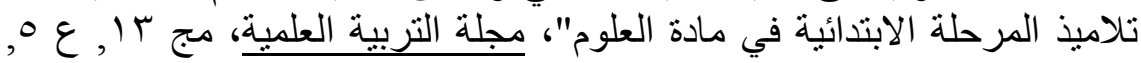

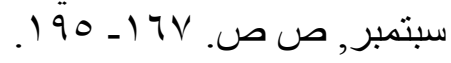

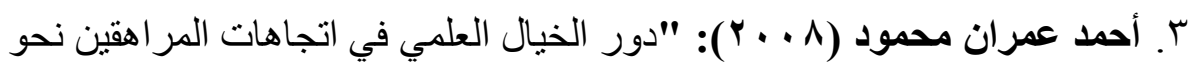

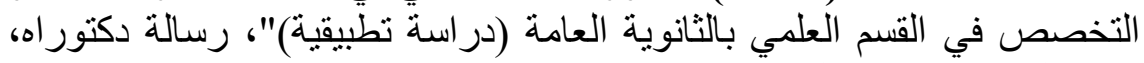

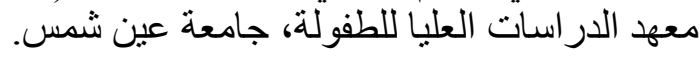




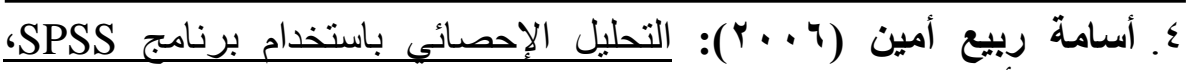

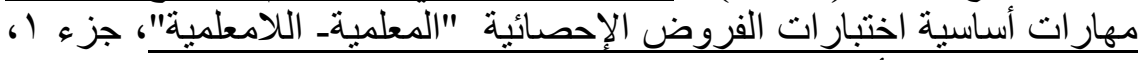
القاهرة، المكتبة الأكاديمية.

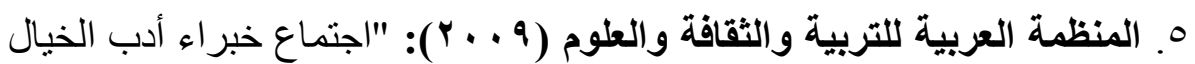

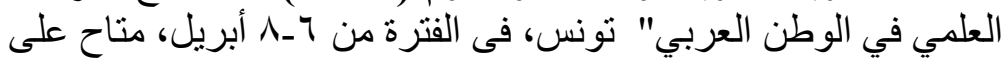

http://www.alecso.org.tn/index.php?option=com_content\&task= view\&id=1304 \& Itemid=296\&lang=ar

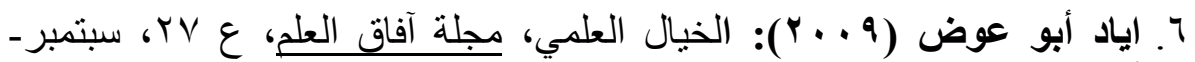

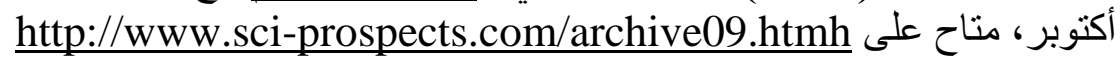

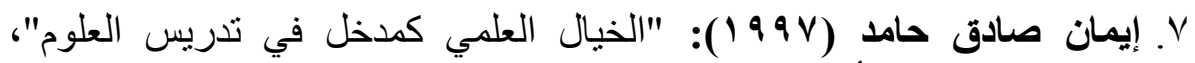

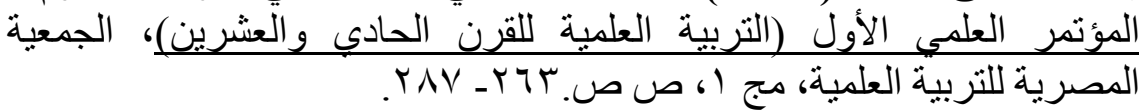

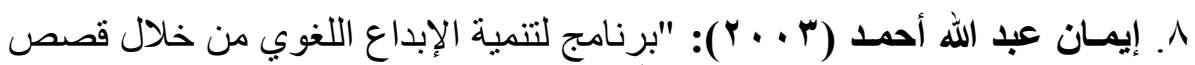

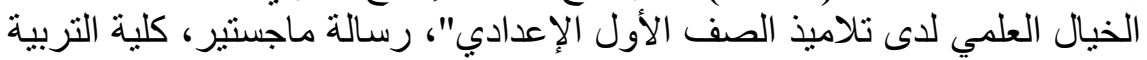
بدمياط، جامعة المنصورة.

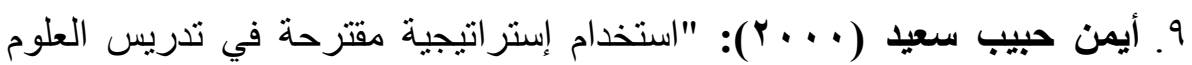

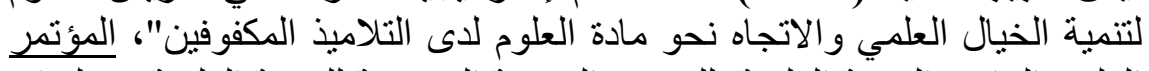

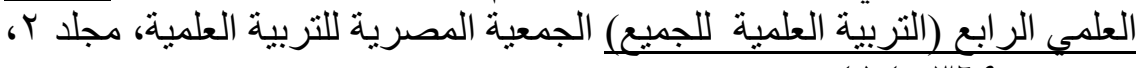
ص ص:

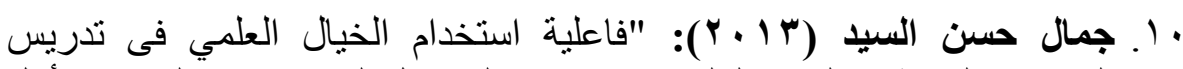

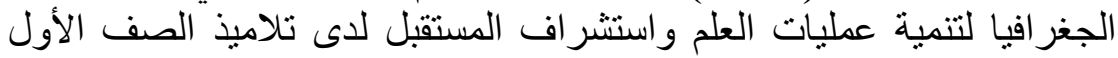

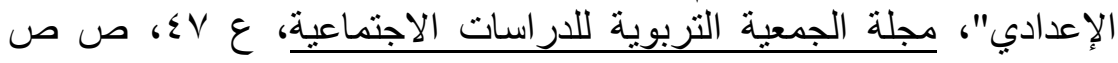

$$
r \cdot \hat{r}-10 r
$$

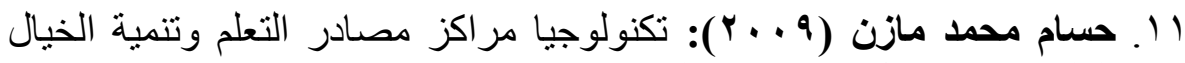

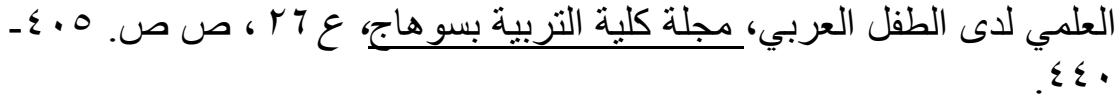

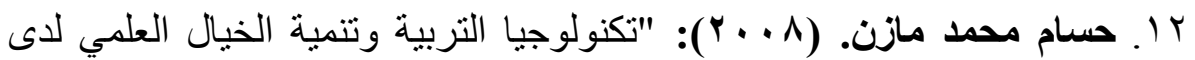

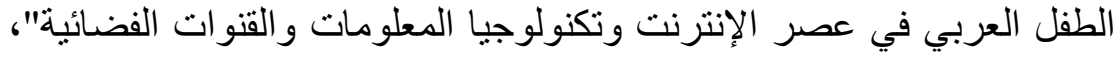

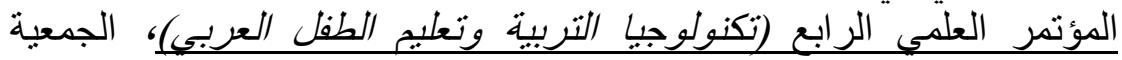

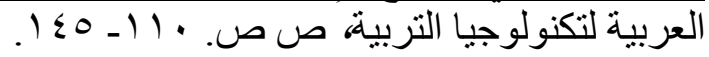

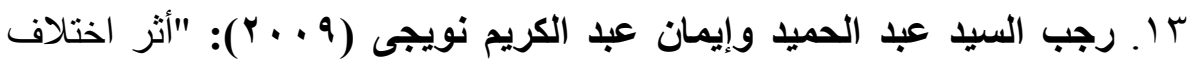

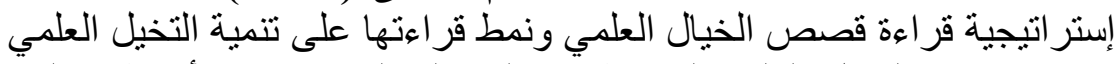

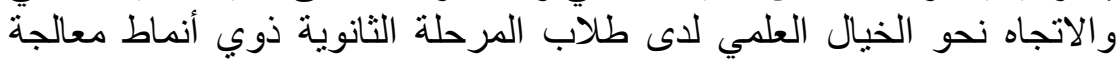


العدد الثانى

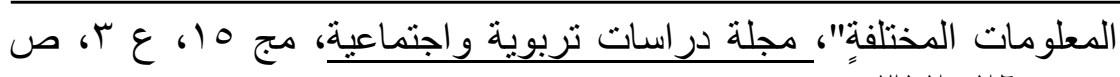

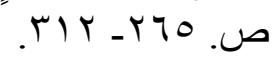

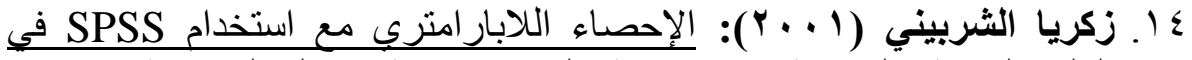

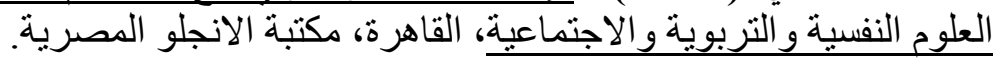

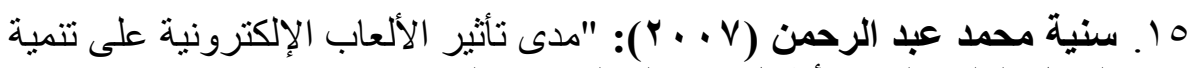

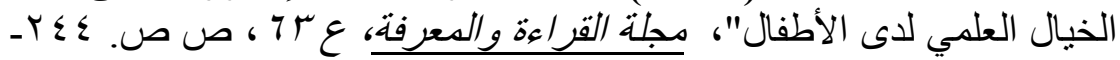

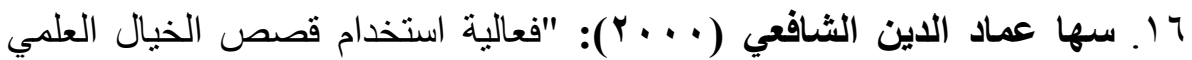
لتدريس العلوم في تنمية التفكير الإبتكارى"، التعال، رسالة ماجستير، كلية التربية،

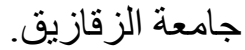

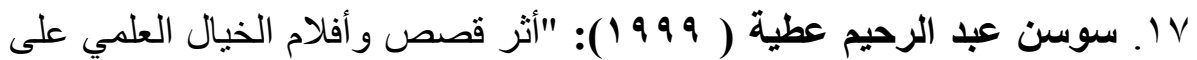

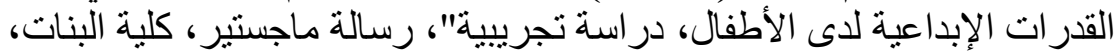
جامعة عين شمس.

11. صالح سعيد حمد (11 • (Y): "جديد التربية"، مجلة التطوير التربوي، سلطنة

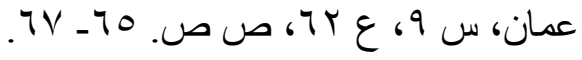

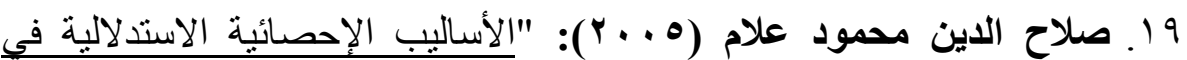

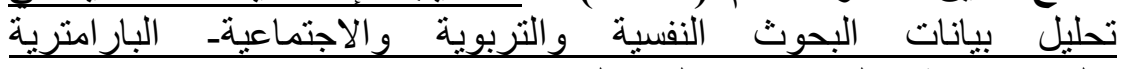

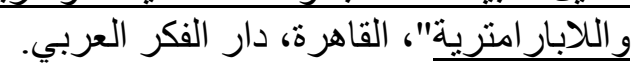

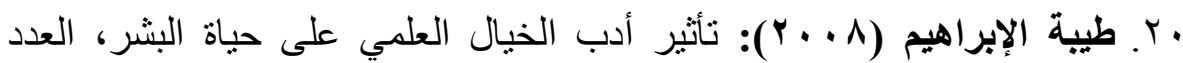

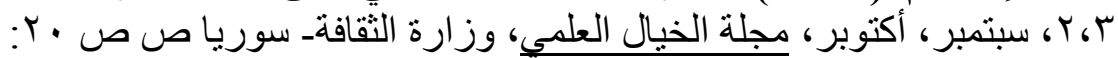

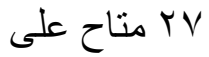

http://moc.gov.sy/archive/downloads/science fiction/02+3.pdf

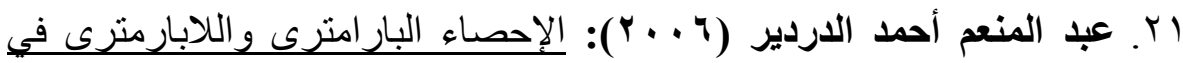

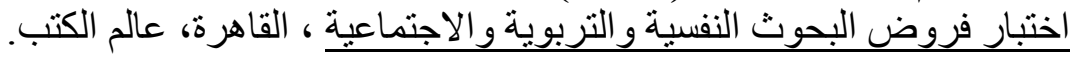

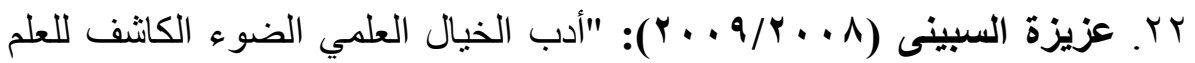

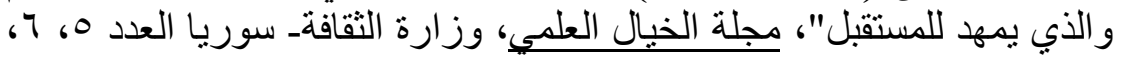

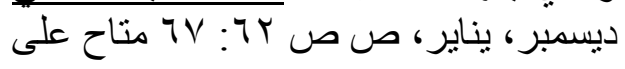
http://moc.gov.sy/archive/downloads/science_fiction/05+6.pdf

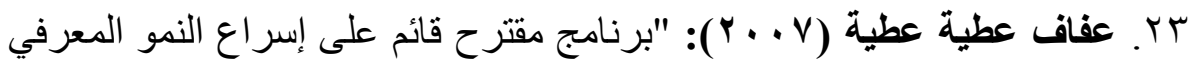

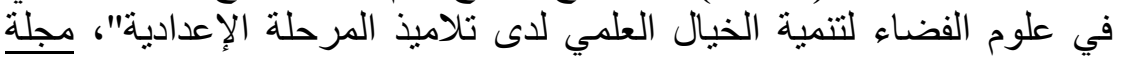

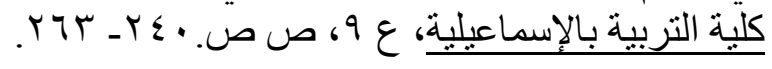




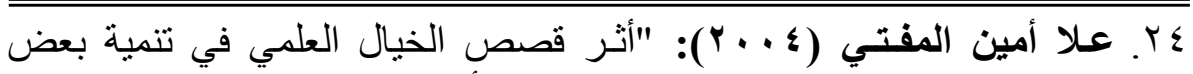
مهار ات التفكير الناقد لدى مجموعات من الأطفال من ( ماجسنتير، كلية البنات، جامعة عين شمس.

هץ. على راشد (V ( . . r): تنمية الخيال العلمي وصناعة الإبداع لدى الأطفال، القاهرة، دار الفكر العربي.

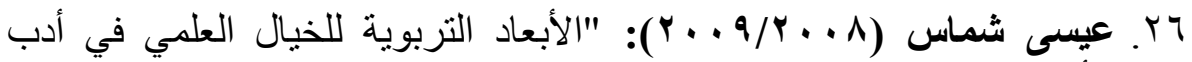

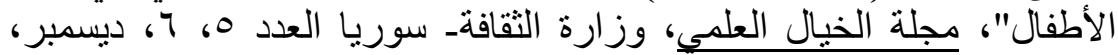

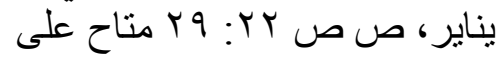

http://moc.gov.sy/archive/downloads/science_fiction/05+6.pdf

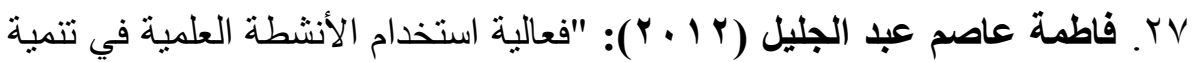

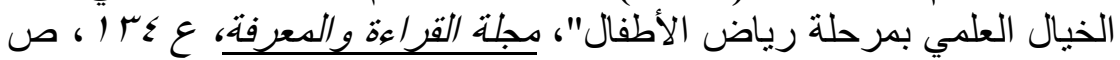

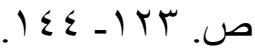
^ץ. فؤاد البهى السيد (19V^)): "علع النفس الإحصائي وقياس العقل البشرى"،

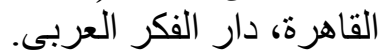

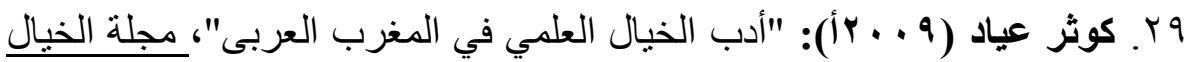

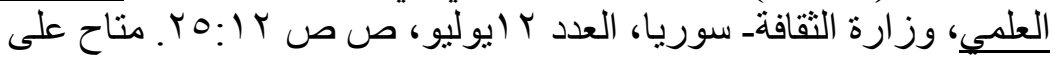
http://moc.gov.sy/archive/downloads/science_fiction/12.pdf

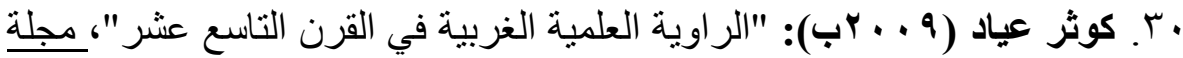

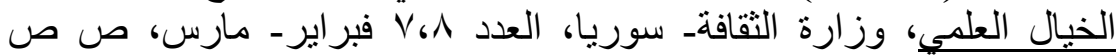

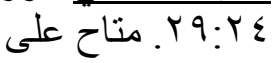

http://moc.gov.sy/archive/downloads/science_fiction/7+8.pdf

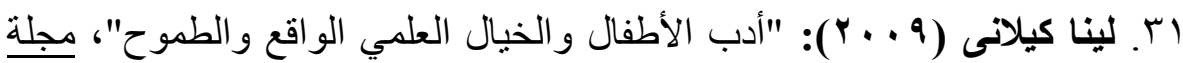

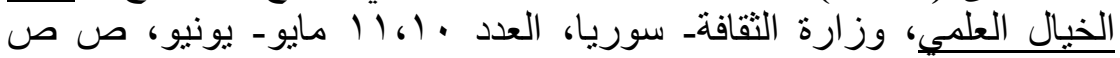

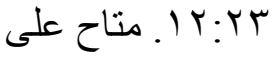

http://moc.gov.sy/archive/downloads/science_fiction/10+11.pdf

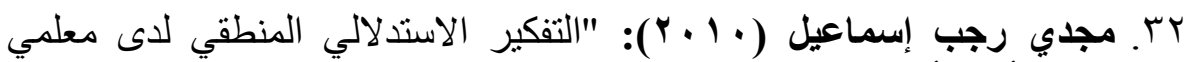

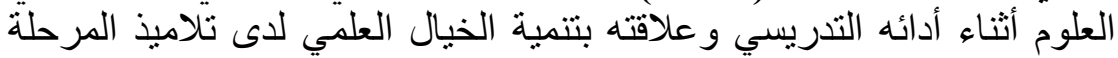

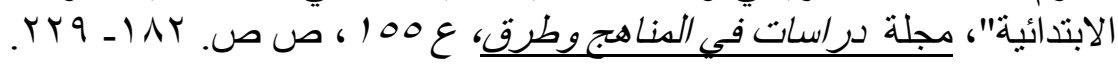

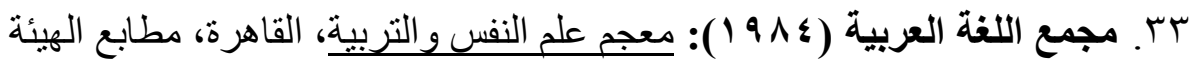
لثشئون المطابع الإميرية.

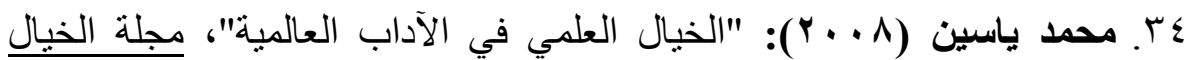

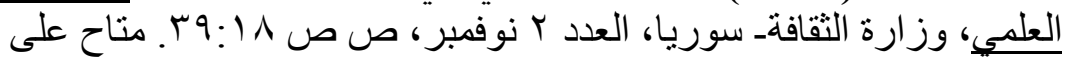


http://moc.gov.sy/archive/downloads/science_fiction/2.pdf

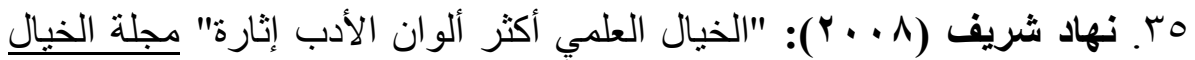

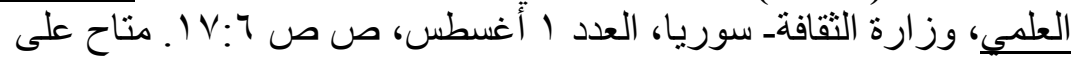
http://moc.gov.sy/archive/downloads/science_fiction/1.pdf

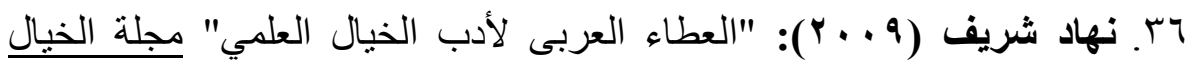

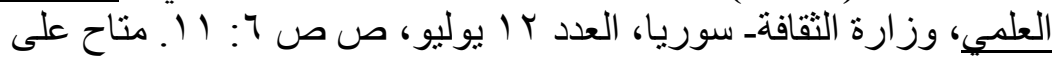
http://moc.gov.sy/archive/downloads/science_fiction/12.pdf

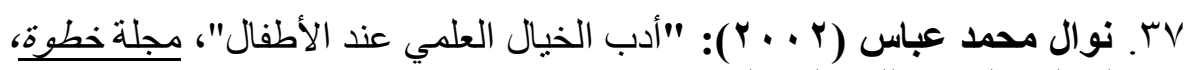

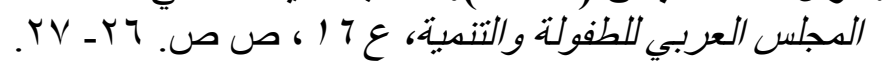

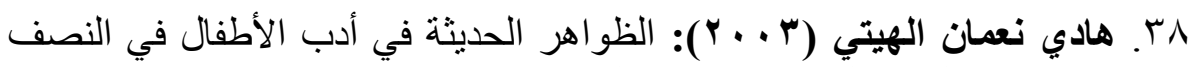

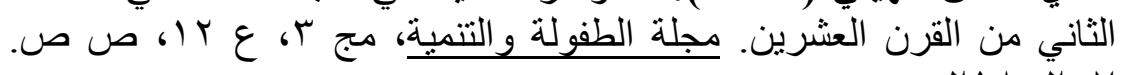
r)

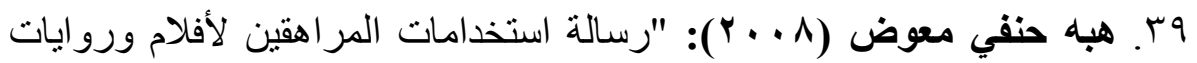

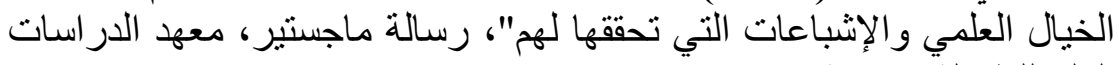
العليا للطفولة، جامعة عين شمس. الأنياعات التي

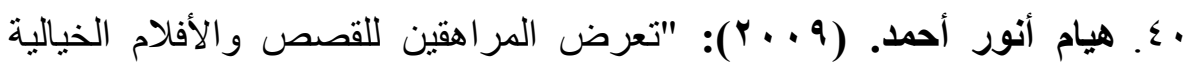

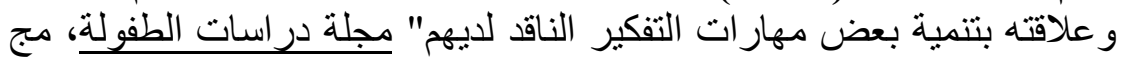

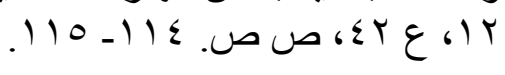

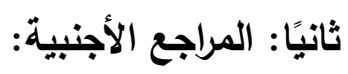

1. Barnett, Michael1, et al. (2006): "The Impact of Science Fiction Film on Student Understanding of Science", Journal of Science Education \& Technology; Apr, Vol. 15, Issue 2, p179- 191.

2. Bixler, Andrea (2007): "Teaching Evolution with the Aid of Science Fiction", American Biology Teacher; Aug, Vol. 69, Issue 6, p337- 340.

3. Cavanaugh, Terence W., Cavanaugh Cathy (2004): "Teach Science with Science Fiction Films :A Guide for Teachers and Library Media Specialists" Ohio, Linworth Publishing. www.ljsquared.com/magbooks/teachscience.pdf 
4. Czerneda, Julie E. (2000) :"Developing Scientific Literacy Using Science Fiction", An Electronic Reviewing Journal of Canadian for Young People, Mar, Vol. 6. Issue 13 .

5. Czerneda, Julie E. (2007): "Science Fiction \& Scientific Literacy", (cover story) Science Teacher; Feb, Vol. 73 Issue 2, p38- 42.

6. Czerneda, Julie E. (2010): Imagine That: The Power of Science Fiction in Science Education. NSTA Reports!; Nov, Vol. 22 Issue 3, p3.

7. Firooznia, Fardad (2006): "Using Science Fiction to Teach a Writing-Intensive, Lab-Based Biology Class for Nonmajors", Journal of College Science Teaching, Mar- Apr, Vol. 35, NO. 5, p26- 31 .

8. Harrett, Jacqueline; Benjamin, Theresa (2009): "Travel with a Time Lord: Using Media to Enhance Literacy", Literacy, Nov., Vol. 43, NO. 3, p134- 142.

9. Kilby-Goodwin, Kristi (2010): "Putting the "Science" in "Science Fiction. "Science Teacher; Jul, Vol. 77, Issue 5, p6063.

10. Laprise, Shari, Winrich, Chuck (2010): "The Impact of Science Fiction Films on Student Interest in Science". Journal of College Science Teaching; Nov/Dec, Vol. 40 Issue 2, p45- 49.

11. Ongel-Erdal, Sevinc; et al (2004): "Science Fiction Movies as a Tool for Revealing Students' Knowledge and Alternative Conceptions" Paper presented at the Annual Meeting of the National, Association for Research in Science Teaching (NARST) Vancouver, Canada.

12. Oravetz, David (2005): "Science \& Science Fiction", Science Scope; Mar, Vol. 28 Issue 6, p20- 22.

13. Perkins, Sid (2004): "What's Wrong With This Picture?". Science News Oct, Vol. 166. Issue 16, p250- 252 
14. Smith, Donald A. (2009): Reaching Nonscience Students through Science Fiction, Physics Teacher, May, Vol. 47, NO. 5, p302- 305,

15. Stutler, Susan Lee (2011): From "The Twilight Zone" to "Avatar": Science Fiction Engages the Intellect, Touches the Emotions, and Fuels the Imagination of Gifted Learners" Gifted Child Today, Spr., Vol. 34, NO. 2, p45- 49.

16. Zoreda, Margaret Lee (2002): "Teaching Short Science Fiction Stories in English as a Foreign Language in Mexico", Paper presented at the Annual Meeting of the Popular Culture Association and American Culture Association (Toronto, Canada, March 13-16) 